\title{
ARTYKUtY
}

Klio. Czasopismo poświęcone dziejom Polski i powszechnym

PL ISSN 1643-8191, t. 59 (3)/2021, s. 81-113

(1) $\Theta$

\section{Informowanie o wyprawie wojennej w końcu XVII w. - przypadek Johanna Reyera i kampanii krymskiej 1689 r.}

\section{Account of a military expedition at the end of the $17^{\text {th }}$ century - the case of Johann Reyer and the Crimean campaign of 1689}

Streszczenie: Artykuł dotyczy niemieckojęzycznej relacji z przebiegu wyprawy wojska rosyjskiego przeciwko Tatarom krymskim wiosną 1689 r. Autorem tego przekazu był pruski dyplomata i tajny radca Johann Reyer. Odbył on w 1688-1689 r. podróż na dwór moskiewski jako poseł księcia-elektora. Analiza źródłoznawcza i treściowa zredagowanej przez niego relacji z owej wyprawy, opartej na pierwotnym tekście rosyjskim, daje możliwość zbadania sposobów percepcji wydarzeń wojennych, jak również ich pojmowania w końcu XVII stulecia. Wskazała ona, że Johann Reyer funkcjonował w podobnych strukturach mentalnych pojmowania i analizy zdarzeń wojennych, jak ówczesne wojskowe otoczenie wodza naczelnego wyprawy, kniazia Vasilija V. Golicyna, wśród którego członków powstała pierwotna rosyjska relacja. Dane dostarczone przez posła na dwór księcia-elektora miały zaledwie

* Wydział Nauk Historycznych Uniwersytetu Mikołaja Kopernika w Toruniu, ul. Władysława Bojarskiego 1, 87-100 Toruń, Krzysztof.Kwiatkowski@umk.pl, ORCID: 0000-0003-1827-3122. 
pewien potencjał informacyjny, ale były pozbawione jakiegokolwiek potencjału analitycznego. Nawet jeśli zatem w kręgu ówczesnych wojskowych pozostających na służbie Hohenzollernów znaleźliby się ludzie zdolni do racjonalnej i systematycznej analizy oraz krytycznej refleksji w kwestiach militarnych, to informatorzy pokroju Reyera nie byliby w stanie dostarczyć im do tego odpowiedniej jakości danych. Przeanalizowany przykład pokazuje, że fenomen racjonalizacji w sprawach militarnych w końcu XVII w. w kręgu elit brandenbursko-pruskich jeszcze się nie rozpoczął.

Abstract: The article pertains to the German-language account of the Russian army's expedition against the Crimean Tatars in the spring of 1689. The author of this narration was a Prussian diplomat and secret councilor Johann Reyer. In 1688-1689 he traveled to the Moscow court as a prince-elector's representative. The source and content analysis of the report from the expedition that he provided, based on the original Russian text, enables an exploration of how military events and warfare were perceived and understood at the end of the $17^{\text {th }}$ century. The analysis has showed that Reyer understood and analyzed the wartime events in the same way as the company of the Russian commander-in-chief Vasily V. Golitsyn, by whose members the original Russian account was written. The data which he provided for the prince-elector's court had some informative potential, but it lacked any analytical purpose of any kind. Therefore, even if among the military men on the Hohenzollern's duty at the end of the $17^{\text {th }}$ century there were people capable of rational and systematic analysis as well as critical reflection regarding military issues, informants such as Reyer were not able to provide them with data of sufficient quality. Johann Reyer's case shows that the phenomenon of rationalization regarding military affairs at the end of the $17^{\text {th }}$ century among the elite of Branderburg-Prussia had not yet begun.

Słowa kluczowe: historia militarna, wczesna nowożytność, Rosja, Brandenburgia-Prusy, wyprawa krymska 1689, prowadzenie wojny, racjonalizacja

Keywords: military history, Early Modern Time, Russia, Brandenburg-Prussia, Crimean campaign 1689, warfare, rationalization

$\mathrm{W}$

czterech ostatnich dekadach XVII stulecia w Europie Zachodniej pojawiły się $\mathrm{w}$ pełni stałe siły zbrojne, w znacznym stopniu zinstytucjonalizowane, tj. zorganizowane wedle skodyfikowanych zasad i bardziej ujednoliconych w stosunku do warunków wcześniejszych norm, w sposób bardziej regularny i systematyczny aniżeli dotychczas organizujące i kontrolujące życie żołnierzy, złożone z wielu organizacyjnie podobnych do siebie, nieprzerwanie funkcjonujących jednostek, tworzone 
i kontrolowane wyłącznie przez aparat państwowy, który uzyskał monopol na władzę militarną na obszarze kraju. Armie tej postaci miały potencjał, aby dość szybko uzyskać wyraźną przewagę nad wojskami organizowanymi w poprzednich dekadach, kształtując tym samym przestrzeń spraw militarnych na zasadach wieloelementowej, złożonej, lecz dość spójnej zarazem i coraz bardziej homogenicznej struktury militarnej ${ }^{1}$. Obok wskazanych powyżej aspektów organizacyjno-strukturalnych, społecznych i politycznych jednym z ważnych elementów tego zjawiska był wyraźny rozwój zdolności przedstawicieli ówczesnych elit (w tym elit wojskowych) do krytycznej autorefleksji i teoretyzującej analizy w zakresie spraw militarnych (m.in. zbierania danych o działaniach wojennych i formułowania na podstawie ich analizy spójnych uogólnień) ${ }^{2}$, który z kolei stopniowo

1 J. Black, War in European history, 1660-1792, „The Essential Bibliography Series", Washington 2009, s. 9-40; idem, European warfare in a global context, 1660 -1815, Abingdon-New York 2007, s. 55-58; idem, Introduction, w: European warfare 1453-1815, ed. J. Black, „Problems in Focus”, London-New York 1999, s. 1-22, 247-249 (przypisy); idem, Beyond the military revolution. War in the seventeenth-century world, Basingstoke-New York 2011, s. 170-187; idem, Warfare in the eighteenth century, London 1999, s. 208; J. Luh, Kriegskunst in Europa 1650-1800, Köln-Weimar-Wien 2004, s. 219-223; por. G. Parker, Zachodnia sztuka prowadzenia wojny, w: Historia sztuki wojennej. Od starożytności do czasów wspótczesnych [oryg.: The Cambridge history of warfare, Cambridge 2005], red. G. Parker, tłum. A. Czarnocki, Warszawa 2008, s. 13-25, tu: s. 14, 16, 21, 23-24; P. Wilson, European warfare 1450-1815, w: War in the early modern world, ed. J. Black, London 1999, s. 177-206, tu: s. 196-200.

2 J. Black, Beyond the military revolution..., s. 193-194; idem, War in European history..., s. 17-20; idem, European warfare in a global context..., s. 79-80; idem, The power of knowledge. How information and technology made the modern world, New Haven-London 2014, s. 227-230; R. Vierhaus, Lloyd und Guibert, w: Klassiker der Kriegskunst, bearb. v. W. Hahlweg, Darmstadt 1960, s. 187-210, tu: s. 188-189. Swoistym ewenementem do pewnego stopnia „wyprzedzającym swoją epokę” był w tym kontekście Raimondo Montecuccoli (*1609, †1680); por. Th. M. Barker, The military intellectual and battle: Raimondo Montecuccoli and the thirty years war, New York 1975. Różnego rodzaju przesłanki tego fenomenu mają metrykę znacznie starszą, sięgającą mniej więcej XIV stulecia (m.in. pisane w językach wernakularnych traktaty dotyczące spraw militarnych, por. m.in. Ch. Allmand, The De re militari of Vegetius. The reception, transmission and legacy of a Roman text in the Middle Ages, Cambridge 2011; V. Schmidtchen, Kriegswesen im späten Mittelalter. Technik, Taktik, Theorie, Weinheim 1990). W odniesieniu do aktywności militarnej w trakcie wojny za wyraz wzrostu poziomu krytycznej refleksji i umiejętności analitycznych w tym zakresie 
doprowadził do swoistego unaukowienia wojskowości zachodnioeuropejskiej, najpóźniej w pierwszej połowie XIX w. ${ }^{3}$ Krajem, w którym owe przemiany rozpoczęły się najwcześniej, było Królestwo Francji doby Ludwika XIV Bourbona (1643/1654/1661-1715)4. Konflikty zbrojne, w które monarchia Króla Słońce angażowała się w ciągu 55 lat jego samodzielnego panowania, przyczyniły się do transferu idei, wiedzy i organizacyjnych rozwiązań - militarnego know-how - do innych krajów europejskich, by wymienić państwa Rzeszy, m.in. Księstwo/Elektorat Bawarii i Elektorat Saksonii ${ }^{5}$ czy Królestwo Hiszpanii ${ }^{6}$. Do grona tych podmiotów politycz-

uznaje się przedstawianie działań wojennych na planach/mapach, jak również samo przygotowywanie wizualizacji terenu na potrzeby konkretnych przedsięwzięć militarnych, która to praktyka zaczęła upowszechniać się stopniowo, począwszy od przełomu XVI i XVII w.; por. ostatnio K. Łopatecki, The influence of maps and plans created in the 1620s in the Netherlands on the development of military concepts in the Polish-Lithuanian Commonwealth, "Przeglad Zachodniopomorski” 2019, R. 34 (63), nr 4, s. 253-283, tu: s. 254-258; i w odniesieniu do konkretnej kampanii: idem, Pierwszy poetycki traktat wojskowy z mapa - Jana Kunowskiego Odsiecz smoleńska. Wykorzystanie kartografii $w$ dziataniach operacyjnych (1616-1617), „Rocznik Lituanistyczny” 2018, t. 4, s. 41-74.

3 Por. m.in. J. Black, War in the nineteenth century, 1800-1914, Cambridge-Malden 2009, s. 27-28, 126, 128-130, 140-142, 205-206; A. Gat, The development of military thought. The nineteenth century, Oxford 1992, s. 1-45; M. Vego, Science vs. the art of war, „Joint Force Quarterly” 2012, issue 66, s. 62-70 (pol. tłum.: Nauka czy sztuka wojenna, tłum. M. K. Ojrzanowski, „Kwartalnik Bellona” 2012, R. 94 (6), nr 4 (671), s. 94-106), tu cyt. wg tłum. pol., s. 97-99; a także H. Münkler, Clausewitz’ Theorie des Krieges, „Würzburger Vorträge zur Rechtsphilisophie, Rechtstheorie und Rechtssoziologie”, H. 30, Baden-Baden 2003.

4 Syntetycznie na ten temat por. m.in. J. A. Lynn, Wojny między państwami, w: Historia sztuki wojennej..., s. 187-209, tu: s. 187-192; także S. Fiedler, Grundriß der Militärund Kriegsgeschichte, Bd. 1: Die stehenden Heere im Zeitalter des Absolutismus 1640-1789, München ${ }^{2} 1980$, s. 38-55; J. Childs, Warfare in the seventeenth century, „Smithsonian History of Warfare”, London 22004, s. 23, 88-89; analitycznie zaś m.in. J. Luh, Kriegskunst in Europa... oraz J. A. Lynn, Wojny Ludwika XIV 1667-1714 [oryg.: The wars of Louis XIV, 1677-1714, London a. o. 1999], tłum. W. Brillowski, Oświęcim 2015 (w pracach dalsza literatura przedmiotu).

5 Por. m.in. A. Querengässer, Die Armee Augusts des Starken im Großen Nordischen Krieg, Berlin 2013; S. Fiedler, op. cit., s. 98-99 (w obu pracach starsza literatura).

6 Por. m.in. Ch. Storrs, The army of Lombardy and the resilience of Spanish power in Italy during the reign of Carlos II (1665-1700), "War in History” 1997, vol. 4, no. 4, s. 371-397; (part II), „War in History” 1998, vol. 5, no. 1, s. 1-22. 
nych zaliczała się także monarchia Hohenzollernów, stanowiąca typowy dla okresu wczesnonowożytnego zlepek różnorodnych krajów, w drugiej połowie XVII w. określany zazwyczaj mianem Brandenburgia-Prusy. W czasie długich, niemal półwiecznych, rządów księcia-elektora Fryderyka Wilhelma (1640-1688) także w krajach Hohenzollernów wyraźnie zarysowała się wspomniana wyżej ewolucja militarna, której efektem było stopniowe utworzenie $\mathrm{w}$ pełni stałych i $\mathrm{w}$ dużej mierze zinstytucjonalizowanych sił zbrojnych ${ }^{7}$.

Z Prus Książęcych - jednej z kilkunastu części składowych monarchii Hohenzollernów - pochodził Johann Reyer, w otoczeniu którego powstał przekaz źródłowy stojący w centrum zainteresowań niniejszego przyczynku. Ten urodzony w Soldau (pol. Działdowo) w 1641 r. mieszczanin, wykształcony w prawie na uniwersytetach w Królewcu i Helmstedt ${ }^{8}$, jako dyplomata w służbie nowego księcia-elektora Fryderyka III odbył między jesienią 1688 a wiosną 1689 r. podróż poselską na dwór moskiewski. Celem poselstwa było wznowienie bardziej intensywnych relacji między domem Hohenzollernów a rosyjskim dworem carskim Romanowów oraz uzyskanie od

7 Por. m.in. Th. Wollchläger, Die „Military Revolution“ und der deutsche Territorialstaat unter besonderer Berücksichtigung Brandenburg-Preußens und Sachsens. Determinanten der Staatskonsolidierung im europäischen Kontext 1670-1740, Norderstedt 2004, który analizuje niektóre aspekty przemian w wojskowości monarchii Hohenzollernów, przede wszystkim problematykę budowy twierdz i rozwoju floty wojennej pod koniec XVII i w pierwszej połowie XVIII w.; syntetycznie zaś: S. Fiedler, op. cit., s. 114-118; Ch. Duffy, Armia Fryderyka Wielkiego [oryg.: The army of Frederick the Great, Warwick ${ }^{2} 1996$ ], tłum. G. Smółka, Oświęcim 2019, s. 15-18; ze starszych studiów por. m.in. C. Jany, Geschichte der preußischen Armee vom 15. Jahrhundert bis 1914, Bd. 1: Von den Anfängen bis 1740, Berlin 1928 (nowe, uzupełnione wydanie, Hrsg. E. Jany, Osnabrück 1967) oraz F. Frhr. von Schroetter, Die brandenburgisch-preußische Heeresverfassung unter dem Großen Kurfürsten, Leipzig 1892.

${ }_{8}$ Por. K. Forstreuter, Reyher, Johann, hasło w: Altpreußische Biographie, Bd. 2: Maltitz - Z, Hrsg. Ch. Krollmann, fortg. v. K. Forstreuter, F. Gause, Marburg/Lahn 1967, s. 552; idem, Preußen und Rußland von den Anfängen des Deutschen Ordens bis zu Peter dem Großen, „Göttinger Bausteine zur Geschichtswissenschaft”, Bd. 23, Göttingen-Berlin-Frankfurt/Main 1955, s. 173. Nagrobek zmarłego 16 marca 1718 r. Reyera znajdował się w katedrze królewieckiej; por. A. Ulbrich, Geschichte der Bildhauerkunst in Ostpreußen vom Ende des 16. bis in die 2. Hälfte des 19. Jahrhunderts, Bd. 2: Vom Ende des 17. bis in die 2. Hälfte des 19. Jahrhunderts, Königsberg 1929, s. 445, Abb. 519. 
ówczesnych decydentów rosyjskiej monarchii szeregu przywilejów dla poddanych elektora. Podróż ta została już w ogólnych zarysach przedstawiona przez Stefana Hartmanna, który w 1987 r. poświęcił jej oddzielny artykuł’, stąd nie wymaga ona tu bliższego naświetlania. Dość powiedzieć, iż aktywność zarówno Johanna Reyera, jak i innych członków jego 23-osobowej grupy pozostawiła po sobie wiele przekazów aktowych przechowywanych dziś w XX. Hauptabteilung (Dział Główny) Geheimes Staatsarchiv PreuBischer Kulturbesitz (Tajne Archiwum Państwowe Pruskiego Dziedzictwa Kulturowego) w Berlinie w zespole Etatsministerium 131a ${ }^{10}$. Wśród tych kilkudziesięciu zbiorów akt znajdują się również materiały dotyczące wojskowości, dotychczas niewykorzystywane przez historyków. Na uwagę zasługuje niemieckojęzyczna relacja na temat wyprawy krymskiej w 1689 r., tym bardziej iż nie jest ona znana badaczom wojskowości rosyjskiej ani brandenbursko-pruskiej ${ }^{11}$. Celem tego artykułu jest przede wszystkim udostępnienie tego źródła historykom, jak również próba dokonania pewnych obserwacji odnośnie do wspomnianego we wstępie fenomenu racjonalizowania autorefleksji w zakresie wojskowości w ramach zarysowanych wyżej przemian w sprawach militarnych następujących od drugiej połowy XVII stulecia.

Zanim podjęta zostanie analiza tego przekazu, należy wpierw przywołać nieco podstawowych informacji o samym przedsięwzięciu militarnym w nim opisywanym. Nie chodzi tu o podjęcie analitycznych studiów nad przebiegiem kampanii krymskiej 1689 r., a jedynie naszkicowanie na podstawie dotychczasowych badań ogólnego kontekstu dla analizowanego dalej tekstu źródłowego. Sam temat kampanii 1689 r. niewątpliwie zasługuje na osobne dokładne zbadanie z uwzględnieniem możliwie pełnego materiału

9 S. Hartmann, Die Mission des brandenburgischen Gesandten Johann Reyer nach Moskau 1688/89, „Jahrbuch Preußischer Kulturbesitz” 1987, Jb. 24, s. 173-193; wcześniej także K. Forstreuter, Preußen und Rußland..., s. 173-175.

10 Por. Geheimes Staatsarchiv Preußischer Kulturbesitz, XX. Hauptabteilung [dalej: GStA PK, XX. HA], EM 131a (Generalia der Herrschaften Serrey und Tauroggen), Nr. 118-119, 127-128, 134-136, 139, 141-152, 155-158, 161-162, 164, 166; por. S. Hartmann, op. cit., s. 178.

${ }^{11}$ Nie uwzględnił jej również w swoim artykule Stefan Hartmann (por. przyp. 9). 
źródłowego, w tym zwłaszcza archiwalnego. Niech więc prezentowana tu relacja obok konkretnego wkładu źródłoznawczego stanowi zachętę dla badaczy przedmiotu.

Kampania krymska 1689 r. była jednym z etapów wojny rosyjsko-tureckiej (1686-1700) ${ }^{12}$. Zawarcie pokoju wieczystego z Rzeczpospolitą w 1686 r. umożliwiło Carstwu Rosyjskiemu zaangażowanie się w wojnę koalicyjną z Portą Ottomańską, co oznaczało wówczas przyłączenie się do tzw. Ligi Świętej zawiązanej dwa lata wcześniej ${ }^{13}$. Wiosną-latem 1687 r. przeprowadzona została pierwsza wyprawa rosyjska na Krym, która nie

12 Por. M. Khodarkovsky, Na granicach Rosji. Budowanie imperium na stepie, 1500-1800 [oryg.: Russian's steppe frontier. The making of a colonial empire, 1500-1800, Bloomington-Indianapolis 2002], tłum. B. Malarecka, Warszawa 2009, s. 145-152; a także D. J. B. Shaw, Southern frontiers in Muscovy, 1550-1700, w: Studies in Russian historical geography, vol. 1, ed. J. H. Bater, R. A. French, London 1983, s. 117-142 oraz B. L. Davies, Warfare, state and society on the Black Sea steppe, 1500-1700, „Warfare and History”, London-New York 2007, s. 17-22; sumarycznie zaś N. S. Kollmann, The Russian Empire 1450-1801, Oxford 2017, s. 57-58, 66-67.

13 K. A. Kočegarov, Rzeczpospolita a Rosja w latach 1680-1686. Zawarcie traktatu o pokoju wieczystym [oryg.: Reč Pospolita i Rossiâ v 1680-1686 godah. Zaklûcenie dogovora o Večnom mire, Moskva 2008 [Речь Посполита и Россия в 1680-1686 годах. Заключение договора о Вечном мире, Москва 2008]], red. T. Szwaciński, Warszawa 2017, s. 329-341, 352-364, 478-484, 498-502, 516-522, 593-595, 598-599; A. G. Gus'kov, K. A. Kočegarov, S. M. Šamin, Russko-tureckâ̂ vojna 1686-1700 gg., „Rossijskaâ istoriâ” 2020, no. 6 [А. Г. Гуськов, К. А. Кочегаров, С. М. Шамин, Русско-туреикая война 1686-1700 г2., „Российская история” 2020, но. 6], s. 30-49, tu: s. 30-32; B. L. Davies, Muscovy at war and peace, w: The Cambridge history of Russia, vol. 1: From early Rus' to 1689, ed. M. Perrie, Cambridge 2006, s. 486-519, tu: s. 514-516; także A. P. Bogdanov, Vnešnaâ politika Rossii i evropejskaâ pečat’ (1676-1689 gg.), „Voprosy istorii” 2003, no. 4 [А. П. БогАанов, Внешная политика России и европейская печать (1676-1689 г2.), „Вопросы истории” 2003, но. 4], s. 26-46, tu: s. 35-43, $45-46$ (przypisy) oraz W. A. Artamonow, Rosja, Rzeczpospolita i Krym w latach 1868-1699, tłum. T. J. Kaźmierczyk, w: Studia i materiaty z czasów Jana III Sobieskiego, red. K. Matwijowski, „Acta Universitatis Wratislaviensis”, nr 1418, „Historia”, nr 102, Wrocław 1992, s. 19-46, tu: s. 24-28 (w tych pracach starsza literatura zagadnienia). Za niezwykle wartościowe konsultacje, zwłaszcza w zakresie literatury rosyjskojęzycznej, jak również za liczne celne uwagi dziękuję Koledze dr. Siergiejowi Polechowowi. 
przyniosła spodziewanych rezultatów ${ }^{14}$, aczkolwiek w efekcie pozyskanych w jej trakcie doświadczeń przy ujściu Samary do Dniepru, a zatem w centralnym sektorze ziem ukrainnych, wzniesione zostało w 1688 r. miasto-twierdza Novobogorodickoe (Новобогородицкое), od rzeki, nad którą ją założono, zwanej również Samarą (Самapa) ${ }^{15}$. Na rozległym obszarze stepowych pustkowi miało to kapitalne wprost znaczenie w kontekście organizowania przyszłych działań zbrojnych w tym rejonie.

14 V. S. Velikanov, Detali pohoda armii V. V. Golicyna v 1687 g., w: Jug Rossii $i$ sopredel'nye strany $v$ vojnah $u$ booružennych konfliktah: materialy Vserossijskoj naučnoj konferencii s meždunarodnym učastiem (Rostov-na-Donu, 22-25 iûnâ 2016 g.), red. G. G. Matišov, Rostov n/D. 2016 [В. С. Великанов, Аетали похода армии В. В. Голицына в 1687 г., w: Юг России и сопредельныц страны в войнах и вооруженных конфликтах: материаль Всероссийской научной конференции смеждународным участием (Ростов-на-Аону, 22-25 июня 2016 г.), реА. Г. Г. Матишов, Ростов н/А. 2016], s. 32-39; A. G. Gus'kov, K. A. Kočegarov, S. M. Šamin, op. cit., s. 32-34; V. A. Artamonov, Rossiâ, Reč Pospolitầ i Krym 1686-1699 godov, w: Slavânskij sbornik, vyp. 5, Saratov 1993 [В. А. Артамонов, Россия, Речь Посполитал и Крым 1686-1699 годов, w: Славянский сборник, вып. 5, Саратов 1993], s. 3-31, 141-147 (przypisy), tu: s. 12-13; ze starszych prac por. np. E. A. Razin, Historia sztuki wojennej, tłum. I. Bukowski, t. 3: Sztuka wojenna manufakturowego okresu wojen [oryg.: Istoriâ voennogo iskusstva, t. 3, Moskva 1957 [История военного искусства, т. 3, Москва 1957]], Warszawa 1964, s. 241-245.

15 Por. ostatnio V. S. Velikanov, Služby Sevskogo polka v 7196 g. i stroitel'svto Novobogorodickoj kreposti, w: Studia internationalia. Materialy V Meždunarodnoj naučnoj konferencii "Zapadnyj region Rossii v meždunarodnyh otnošeniâh $X-X X v v$." (29 iûnâ-1 iûlâ 2016 goda), Brânsk 2016 [В. С. Великанов, Службъц Севского полка в 7196 г. и строительство Новобогородицкой крепости, w: Studia internationalia. Mатериаль V Международной научной конференщии „Западный регион России в международньх отномениях $X-X X$ вв." (29 июня-1 июля 2016 года), Брянск 2016], s. 60-66, tu: s. 62-65; A. G. Gus'kov, K. A. Kočegarov, S. M. Šamin [А. Г. Гуськов, K. А. Кочегаров, С. М. Шамин], op. cit., s. 35-36; wcześniej m.in. С. В. O’Brien, Russia under two tsars 1682-1689. The regency of Sophia Alekseevna, „University of California Publications in History", vol. XLII, Berkeley-Los Angeles 1952, s. 134 oraz E. A. Razin, op. cit., s. 245 . 
Kampania 1689 r. była drugim z kolei większym przedsięwzięciem wojska rosyjskiego wysłanego przeciwko Chanatowi Krymskiemu w trakcie wojny 1686-1700 ${ }^{16}$. Wojsko carskie zostało zebrane już w lutym 1689 r. w kilku zgrupowaniach w łącznej liczbie ca 112000 ludzi ${ }^{17}$, którzy mieli do

16 Główną podstawą źródłową do współczesnej analizy przebiegu wyprawy krymskiej 1689 r. pozostają ciągle przede wszystkim zapiski generała Patrica Gordona (por. Diary of generel Patrick Gordon of Auchleuchries 1635-1699, vol. 4: 1684-1689, ed. D. Fedosov, Aberdeen 2013, s. 235-251; wydawca pamiętnika przytacza we wstępie trzy przekazy rosyjskie; por. idem, Introduction: From Kiev to Moscow, w: Diary of generel Patrick Gordon..., s. vii-xlii, tu: s. xxviii, przyp. 56-58), sporządzane w trakcie kampanii doniesienia kniazia Vasilija Vasileviča Golicyna (por. N. G. Ustâlov, Istoriâ carstvovaniâ Petra Velikogo, t. 1, Peterburg 1858, Priloženie: Doneseniâ knâzâ B. B. Golicyna i tovariščej ego vo vremâ krymskago pohoda v" 1689 godu [Н. Г. Устрянов, Исторія чзарствованія Петра Великого, т. 1, Петербург 1858, Приложение № 9: Аонесенія князя В. В. Голищььна и товарищей его во время крыммскаго похода въ 1689 году], s. 356-382), oparta przynajmniej w części na nich relacja francuskojęzyczna opublikowana w 1698 r. (F. de la Neuville, Relation campagne ou Expedition des Moskovites en Crimée l'an 1689, w: idem, Relation curieuse, et nouvelle de Moscovie, Paris 1698, s. 86-109; por. nowe wydanie i rosyjskie tłumaczenie tejże relacji: De la Nevill', Zapiski o Moskovii, red. V. D. Nazarov, U. P. Malinin, predislovie, podgotovka teksta, perevod i kommentarii A. S. Lavrov, Moskva-Dolgoprudnyj 1996 [Ае ма Невимиь, Записки о Московии, реА. В. А. Назаров, Ю. П. Малинин, преАисловие, подготовка текста, перевод и комментарии А. С. Аавров, Москва-АолгопруАный 1996], s. 82-88 (tekst francuski), 144-150 (tłumaczenie rosyjskie)), relacja Jiřego Davida (por. Irži David, Sovremennoe sostoânie Velikoj Rossii, ili Moskovii, „Voprosy istorii” 1968, nr 1 [Иржи АавиА, Современное состояние Великой России, или Московии, „Вопросы истории" 1968, nr 1], s. 123-131) oraz rosyjski diariusz kampanii (por. A. V. Lavrent'ev, "Mernoe koleso» Krymskogo pohoda. 1689 g., w: A. V. Lavent'ev, Ljudi i vešći. Pamâtniki russkoj istorii i kul'tury XVI-XVIII vv., ih sozdateli i vladel'cy, Moskva 1997 [А. В. Ааврентьев, «Мерное колесо» Крымского похода. 1689 г., w: А. В. Ааврентьев, Аюди и веши. Памятники русской истории и культурь XVI-XVIII вв., их создатели и владельцы, Москва 1997], s. 137-150, Priloženie [Приможение], s. 146-150). Przekazy pisane strony krymskiej (por. np. Halim Giraj-sultan, Pozovyj kust hanov, ili Istoriâ Kryma, transkripciâ, perevod, pereloženiâ K. Useinov, red. N. S. Sejtâg'eb, Simpferopol' 2008 [Халим Гирай-султан, Розовый куст ханов, или История Крыма, транскрипция, перевоА, переложения А. ИАьми, составление приложений и пояснения К. Усеинов, реА. Н. С. Сейтягьев, Симферополь 2008], s. 92-93) były dotychczas w literaturze przedmiotu mniej intensywnie wykorzystywane.

17 N. G. Ustrâlov [Н. Г. Устрялов], оp. cit., s. 217-218 oraz Priloženie nr 9 [Приможение nr 9]: Vedomost" vojskam”, byvžim” v" krymskom" pohode 1689 goda [Вгдомость войскамг, бььиимг въ крымскомг походп 1689 года], s. 386-387; za nim 
dyspozycji znaczny park artyleryjski obejmujący prawdopodobnie ca 350 dział. Wodzem naczelnym, tak jak w wyprawie 1687 r., był kniaź-wojewoda Vasilij Vasilevič Golicyn ${ }^{18}$. Pierwszym celem pochodu rozpoczętego z Sum 27 (17) marca była wspomniana wyżej twierdza Novobogorodickoe, gdzie 30 (20) kwietnia nastąpiło połączenie sił rosyjskich ze sprzymierzonym wojskiem kozackim w sile co najmniej ca 30000 ludzi (w tym Kozaków zaporoskich ${ }^{19}$. Z uwagi na trudności aprowizacyjne, które w dużej mierze zaważyły na przebiegu wyprawy z 1687 r., sześć odrębnych zgrupowań

m.in. C. B. O’Brien, op. cit., s. 137; L. Hughes, Sophia, regent of Russia: 1657-1704, New Haven-London 1990, s. 211; V. M. Zaruba, Pohodi rosijs'kih ta ukraïns'kih vijsk na Krim u 1687 j 1680 rr., „Ukraïns'kij ìstoričnij žurnal” 1992, nr 9 [В. М. Заруба, Походи російсъких та українських війск на Крим у 1687 й 1689 рр., „Український історичний журнал” 1992, № 9], s. 65-75, tu: s. 70; a ostatnio także K. Rędzia, Strzelcy moskiewscy w latach 1550-1723, [Oświęcim 2018], s. 84 i A. G. Gus'kov, K. A. Kočegarov, S. M. Šamin [А. Г. Гуськов, К. А. Кочегаров, С. М. Шамин], ор. cit., s. 36; А. V. Černov, Vooružennye sily Russkogo Gosudarstva v XV-XVII v.v., Moskva 1954 [А. В. Чернов, Вооруженныце силь Русского Государства в XV-XVII в.в., Москва 1954], s. 195-196; а za nim także E. A. Razin, op. cit., s. 246 oraz B. L. Davies, Warfare..., s. 181 podają liczbę 117446 ludzi, aczkolwiek bez przytoczenia źródła informacji. Również D. Fedosov, op. cit., s. xxvii, pisze - za A. V. Černovem - o 117500 ludziach na wyprawie. Pewne jest, iż liczba ludzi w wojsku szybko zaczęła maleć z uwagi na straty marszowe, spowodowane różnymi czynnikami. W Novobogorodickoe zostawiono także pewien kontyngent, a również na trasie marszu z tej twierdzy w kilku miejscach wzniesiono umocnienia polowe obsadzone pewną liczbą żołnierzy.

18 O nim por. m.in. A. S. Lavrov, Vasilij Vasil'evič Golicyn, „Voprosy istorii” 1998, nо. 5 [А. С. Аавров, Василий Васильевич Голищъцн, „Вопросы истории” 1998, но. 5], s. 61-72; zaś w polskiej literaturze stosunkowo niedawno P. Krokosz, Wasyl Golicym - niespetniony rosyjski reformator, „Studia Historyczne” 2005, R. 48, z. 1 (189), s. 15-27 (w obu pracach dalsza literatura).

19 N. G. Ustrâlov [Н. Г. Устрялов], op. cit., s. 219-220; L. Hughes, op. cit., s. 211. W literaturze przedmiotu podawane są różne szacunki liczbowe co do wielkości sił kozackich; por. E. A. Razin, op. cit., s. 246 (30 000-40 000 kozaków); za nim L. Podhorodecki, Chanat Krymski i jego stosunki z Polska w XV-XVIII w., Warszawa 1987, s. 227; B. L. Davies, Muscovy..., s. 516, w odniesieniu do obu wypraw krymskich podaje szacunki rzędu 30 000-50 000 ludzi; w innej swojej pracy pisze zaś o 30 000-40 000 ludzi; por. idem, Warfare..., s. 181; W. A. Artamonow, op. cit., s. 32, szacował te siły na ca 50000 ludzi; podobnie V. M. Zaruba [B. M. Заруба], op. cit., s. 71. Natomiast C. B. O’Brien, op. cit., s. 137, podawał jedynie 16000 Kozaków hetmana Mazepy. 
(tzw. razrâdów) wojska ${ }^{20}$ szło częściowo oddzielnymi trasami bądź niekiedy jedno za drugim, dzięki czemu były w stanie w efektywniejszy sposób zaopatrywać się w czasie pochodu w wodę pitną, a zwłaszcza w paszę dla koni $^{21}$. Z Novobogorodickoe (Samara) wojsko zabrało ze sobą żywność przewidywaną na dwumiesięczną kampanię̨2 . Połączone wojska rosyjskie i kozackie udały się spod Samary w kierunku południowym, zmierzając trasą sprzed dwóch lat. W dniu 13 (3) maja siły te dotarły nad rzekę Jančokrak (Янчокрак), w okolicę chutoru Bolszoj Lug (Большой Ауг), skąd przed dwoma laty zarządzono odwrót ${ }^{23}$. W rejonie na południe od dolnego biegu Dniepru i tureckiej twierdzy Kyzy-Kermen (Kazy-Kermen, tur. Gazi Kirmân), w okolicach uroczysk i bałek Zelenaâ Dolina (Земеная долина) i Černaâ Dolina (Черная долина) ${ }^{24}$ oraz dalej na południe, na trasie wiodącej nad rzekę Kalančak (Каманчак) doszło 25-27 (15-17) maja do manewrowych bitew z wojskiem krymskim, które przy efektywnym udziale rosyjskiej artylerii i taboru zakończyły się odwrotem sił krymskich ${ }^{25}$. Ści-

20 B. L. Davies, Warfare.., s. 181; L. Podhorodecki, op. cit., s. 227; także E. A. Razin, op. cit., s. 246.

21 Por. rozważania Patrica Gordona dotyczące przygotowań kampanii 1689 r. poczynione w pierwszej połowie marca, Diary of generel Patrick Gordon..., s. 238-239: The Embrio of a Memorandum concerning considerations on our present expedition.

22 E. A. Razin, op. cit., s. 246; za nim w literaturze polskojęzycznej L. Podhorodecki, op. cit., s. 227-228; także jego popularnonaukowa książka: idem, Tatarzy, Warszawa ${ }^{1} 1971 ;{ }^{2} 2010$ (tu cytowane wyd. 2), s. 201. W twierdzy pozostawiono ponadto ca 6300 ton zboża; por. B. L. Davies, Warfare..., s. 181.

23 L. Hughes, op. cit., s. 211; B. L. Davies, Warfare.., s. 181; por. też: V. S. Velikanov, Detali pohoda... [B. С. Вемиканов, Аетали nохода...], s. 35; także V. M. Zaruba [B. М. Заруба], op. cit., s. 71.

24 Pierwsze uroczysko należy lokalizować w okolicy dzisiejszej miejscowości Bohdanivka (Богданівка) w obwodzie zaporoskim $\left(47^{\circ} 06^{\prime} 21^{\prime \prime} \mathrm{N}, 36^{\circ} 02^{\prime} 49^{\prime \prime} \mathrm{E}\right)$, które na rosyjskiej mapie topograficznej 1 : 200000 z początków XX w. opisane jest jako Zelenyj pad” (3eменый падъ); por. niemiecką wersję tejże mapy: Rußland 1 : 100000, Blatt Nr. L-35-V Ost. Drugie uroczysko położone było w miejscu współczesnej wsi Čorna Dolina (Чорна Аолина) w obwodzie chersońskim $\left(46^{\circ} 31^{\prime} 43^{\prime \prime} \mathrm{N}, 33^{\circ} 28^{\prime} 16^{\prime \prime} \mathrm{E}\right)$, ca $7 \mathrm{~km}$ na południowy zachód od pierwszego; por. Rußland 1 : 100000, Blatt Nr. L-36-VIII Ost.

25 N. G. Ustrâlov [Н. Г. Устрямов], op. cit., s. 221-225; C. B. O’Brien, op. cit., s. 137-138; L. Hughes, op. cit., s. 211; B. L. Davies, Warfare..., s. 181-182; D. Fedosov, op. cit., s. xxviii; V. M. Zaruba [B. M. Заруба], op. cit., s. 71-72; A. S. Lavrov, Regentstvo 
gając przeciwnika, wojska Golicyna 30 (20) maja dotarły do Przesmyku Perekopskiego ${ }^{26}$. Stepowe obszary całego północnego przedpola przesmyku były spalone i w rezultacie nie nadawały się do eksploatacji jako rejon pozyskiwania jakichkolwiek zapasów paszy czy żywności. Wobec wyczerpywania się środków aprowizacyjnych przywiezionych ze sobą przez wojsko rosyjskie i kozackie perspektywa dalszych działań w odległości ca $300 \mathrm{~km}$ od najbliższej bazy zaopatrzeniowej w Novobogorodickoe nie przedstawiała się korzystnie. Także wejście na Krym nie było przedsięwzięciem prostym, na drodze stała bowiem silnie obsadzona tatarska twierdza Or Kap1 (ros. Perekop/Перекоп) oraz obsadzony przez siły chana siedmiokilometrowej długości tzw. Wał Turecki na Przesmyku Perekopskim, przed którym w dodatku przebiegała głęboka na 23-30 $\mathrm{m}$ fosa ${ }^{27}$. Należało więc nie tylko zdobyć twierdzę (będącą silnie ufortyfikowanym miastem), ale także opanować Wał, by następnie wykorzystać jego jedyną bramę bądź utworzyć w nim inżynieryjne punkty przeprawowe w celu przeprowadzenia przez przesmyk licznej artylerii. Wszystkie te okoliczności spowodowały, iż Vasilij V. Golicyn nie zdecydował się na atak i w rezultacie prowadzonych już od kilku dni za pośrednictwem posłów rozmów z chanem Selimem Girejem ${ }^{28}$

carevny Sof'i Alekseevny. Služiloe obščestvo i bor'ba za vlast'v verhah Russkogo gosudarstva v 1682-1689 godah, Sankt Petersburg 2017 [А. С. Аавров, Регентство иаревны Софьи Алексеевны. Служилое общество и борьба за власть в верхах Русского государства в 1682-1689 годах, Санкт Петербург 2017], s. 151-152; L. Podhorodecki, Chanat Krymski..., s. 228; E. A. Razin, op. cit., s. 247, 249.

26 N. G. Ustrâlov [Н. Г. Устрялов], op. cit., s. 225-232; С. В. O’Brien, op. cit., s. 138; L. Hughes, op. cit., s. 212; B. L. Davies, Warfare..., s. 182; D. Fedosov, op. cit., s. xxviii; V. M. Zaruba [B. M. Заруба], op. cit., s. 72; L. Podhorodecki, Chanat Krymski..., s. 228.

27 B. L. Davies, Warfare..., s. 182; E. A. Razin, op. cit., s. 249; L. Podhorodecki, Chanat Krymski..., s. 227. Pierwsze umocnienia na istmie perekopskim wzniesione zostały z polecenia chana Sahiba Gireja w latach 40. XVI w., kiedy to władca krymski starał się skonsolidować większość ord tatarskich i osiedlić ich na Półwyspie Krymskim, na który wejście miało być chronione przez potężne fortyfikacje; por. L. Podhorodecki, Tatarzy..., s. 156.

28 N. G. Ustrâlov [Н. Г. Устрялов], op. cit., s. 234, 253; V. A. Artamonov [B. A. Apтамонов], op. cit., s. 17; D. Fedosov, op. cit., s. xxviii; A. G. Gus'kov, K. A. Kočegarov, S. M. Šamin [А. Г. Гуськов, К. А. Кочегаров, С. М. Шамин], оp. cit., s. 37. 
31 (21) maja zarządził odwrót swoich wojsk na północ ${ }^{29}$. Po ponad miesięcznym odwrocie 9 lipca (29 czerwca) nad rzeką Mierło (Мepıo, lewy dopływ Worskli) wódz rozwiązał wojsko i rozpuścił je do domów ${ }^{30}$. Działania rosyjskie, aczkolwiek z punktu widzenia dworu moskiewskiego zakończone niepowodzeniem, w szerszej skali, tj. z perspektywy Ligi Świętej, odegrały pozytywną rolę, skutkowały bowiem czasową nieobecnością na węgierskim i mołdawskim teatrze działań wojennych po stronie osmańskiej jej tatarskiego sojusznika ${ }^{31}$. Następstwa tego drugiego już z kolei, zorganizowanego na dużą skalę, lecz zakończonego niezrealizowaniem zamierzonych celów, przedsięwzięcia militarnego nie ograniczyły się do spraw militarnych. Nie tylko doprowadziło ono bowiem do poniechania przez dwór moskiewski planów podporządkowania zwierzchnictwu rosyjskiemu Chanatu Krymskiego, ale także znacząco osłabiło pozycję wojewody Golicyna wśród

29 N. G. Ustrâlov [Н. Г. Устрялов], op. cit., s. 233-237; C. B. O’Brien, op. cit., s. 140-141; L. Hughes, op. cit., s. 212; D. Fedosov, op. cit., s. xxviii; V. M. Zaruba [B. М. Заруба], op. cit., s. 73.

30 N. G. Ustrâlov [Н. Г. Устрялов], op. cit., s. 242; E. A. Razin, op. cit., s. 250. Golicynowi czyniono później na dworze zarzuty z powodu całkowitego rozwiązania wojska, przez co południowo-zachodnie rubieże ukrainne pozostały na drugą połowę roku bez należytej osłony. V. M. Zaruba [B. M. Заруба], op. cit., s. 74, idąc za źródłem kozackim/ /ukraińskim, wskazuje, iż wojsko rozwiązano już 4 lipca (24 czerwca) nad rzeką Kolomak (Коломак). Sam Golicyn przybył do Moskwy 29 (19) lipca; por. C. B. O’Brien, op. cit., s. 141.

31 Halim Giraj-sultan [Халим Гирай-султан], op. cit., s. 92-94; por. A. G. Gus'kov, K. A. Kočegarov, S. M. Šamin [А. Г. Гуськов, К. А. Кочегаров, С. М. Шамин], оp. cit., s. 37; R. Mihnea, La participation de la Russie aux guerres de la Sainte Alliance, "Études Balkaniques" 1979, vol. 15, s. 94-103; za tym ostatnim podobnie R. Murphey, Sztuka wojenna Turków osmańskich w latach 1500-1700 [oryg.: Ottoman warfare 1500-1700, „Warfare and History”, London 1999], tłum. M. Młynarz, Oświęcim 2012, s. 29-30, aczkolwiek wyraźnie przeszacował liczebną wielkość pomocy tatarskiej, bezkrytycznie przyjmując informacje współczesnego wydarzeniom tureckiego kronikarza Evliyi Çelebiego. W polskojęzycznej literaturze m.in. L. Podhorodecki, Chanat Krymski..., s. 228; w rosyjskojęzycznej G. K. Babuškina, Meždunarodnoe značenie krymskih pohodov 1687 i 1689 gg., „Istoričeskie zapiski” 1950, t. 33 [Г. К. Бабушкина, Международное значение крылмских походов 1687 и 1689 г2., „Исторические записки” 1950, т. 33], s. 158-177; w niemieckojęzycznej zaś R. Wittram, Peter I. Czar und Kaiser. Zur Geschichte Peters des Großen in seiner Zeit, Bd. 1, Göttingen 1964, s. 77. 
ówczesnych elit rosyjskich, i w rezultacie spowodowało upadek rządów regencyjnych carewny Sofii Aleksejevnej ${ }^{32}$ w tym samym jeszcze roku.

Dokładną analizę prezentowanej tu relacji o wyprawie krymskiej 1689 r. musi poprzedzić krytyka zewnętrzna i wewnętrzna tegoż przekazu źródłowego. Tekst napisany na złożonym arkuszu papieru in folio, na nieco ponad trzech stronach, ma charakter brudnopisu, o czym świadczą stosunkowo liczne skreślenia tudzież poprawki ${ }^{33}$. Relacja została sporządzona $\mathrm{w}$ języku niemieckim. Pozostaje ona anonimowa, zapewne $\mathrm{z}$ uwagi na formę brudnopisową. Kilkakrotne wtręty francuskie (rendewus, blessirts, bataillen ${ }^{34}$ wskazują z jednej strony jednoznacznie na autorstwo osoby posługującej się tym językiem, a więc zapewne dyplomaty. Z drugiej strony imiona rosyjskie zapisane łacińskim duktem zostały oddane poprawnie pod względem językowym, co znowu świadczy o znajomości przez redaktora tekstu języka rosyjskiego. Wreszcie zastosowanie spolonizowanej wersji otčestva Iwana Mazepy (Szczepanowicz zamiast 'Stiepanowicz') ${ }^{35}$ pozwala ostrożnie przypuszczać, że autor znał również język polski. Na podstawie porównawczej analizy paleograficznej kilku rękopisów-autografów Reyera, jak również dopiero co przytoczonych przesłanek filologicznych, można stwierdzić, iż tekst wyszedł spod ręki tegoż dyplomaty ${ }^{36}$. Musiało się to stać

32 C. B. O'Brien, op. cit., s. 141-146; R. K. Massie, Peter the Great. His life and world, New York 1980, s. 116-119; R. Wittram, op. cit., s. 95-102; L. Hughes, op. cit., s. 224-241; P. Krokosz, op. cit., s. 25-27; Z. Wójcik, Dzieje Rosji 1533-1801, Warszawa 1971, s. 210-212; A. S. Lavrov [А. С. Аавров], op. cit., s. 157-182.

33 Por. niżej: Aneks źródtowy, s. 109-113.

34 Ibidem, s. 110.

35 Ibidem.

${ }^{36}$ Por. akta sporządzone (i osobiście podpisane) przez brandenbursko-pruskiego posła: GStA PK, XX. HA, EM 131a, Nr. 132, 139, 141-143, 146-147, 150, 152, 156 (z 1688-1689); GStA PK, I. HA, Rep. 9 (Polen), Nr. 27 s 3, k. 46r-49r (z 1696 r.); dobrą znajomość języka francuskiego potwierdza chociażby jedna z relacji Reyera z czasu omawianego tu poselstwa do Moskwy sporządzona w tym języku; por. GStA PK, XX. HA, EM 131a, Nr. 136. Za wskazanie autografów Reyera i rzeczowe konsultacje w kwestii jego duktu oraz baz druków ulotnych z XVII stulecia dziękuję w tym miejscu Koledze dr. Marcinowi Swobodzińskiemu. Johann Reyer od 1668 r. pozostawał w służbie księcia Bogusława Radziwiłła, a następnie jego córki Ludwiki Karoliny, mając podczas licznych pobytów na Litwie okazję do nauki języka polskiego i ruskiego/rosyjskiego, których znajomość niewątpliwie pogłębiał podczas kolejnych poselskich misji w tym kraju już 
już w Królewcu, do którego wracające z Rosji poselstwo elektorskie przyjechało 14 (4) maja 1689 r. ${ }^{37}$ Reyer nie brał osobiście udziału w wyprawie krymskiej i nie był naocznym świadkiem opisywanych w relacji wydarzeń. W dniu, kiedy wracał właśnie do miasta nad Pregoła, siły rosyjskie dopiero zmierzały w kierunku Krymu.

O ile zachowany brudnopis jest autografem Reyera, o tyle sama relacja nie jest oryginalnym tekstem brandenbursko-pruskiego dyplomaty. Otóż należy zauważyć, że kilka miejsc w tekście wskazuje jednoznacznie na identyfikowanie się autora relacji z wojskiem rosyjskim, które jest nazywane „naszym” 38 , podobnie jak znajdujące się w nim oddziały kawalerii ${ }^{39}$. Jasne jest, że nie może w tym przypadku chodzić o osobę Reyera. Obserwacje te prowadzą do istotnego wniosku, iż omawiana relacja o wyprawie krymskiej 1689 r. miała dwie redakcje. Pierwsza z nich została sporządzona w rosyjskim kręgu wojskowym, drugą zaś opracował Reyer, przy czym tekst rosyjski służył tu za podstawę. W zakończeniu niemieckiej relacji jest mowa o „wieściach” (zeithungen), które jeszcze z obozu wojskowego (auß dem lager) zostały dostarczone „tutaj” (anhero) przez dwóch carskich stolników biorących dotychczas udział w wyprawie ${ }^{40}$. Mamy zatem do czynienia

z ramienia księcia-elektora Fryderyka III w 1680 r.; por. K. Forstreuter, Reyher, Johann..., s. 552; A. Kamieński, Polska a Brandenburgia-Prusy w drugiej potowie XVII wieku. Dzieje polityczne, Poznań 2002, s. 201.

37 GStA PK, XX. HA, EM 131a, Nr. 159; por. S. Hartmann, op. cit., s. 186.

38 Por. niżej: Aneks źródtowy, s. 112.

39 Ibidem, s. 111.

40 Ibidem, s. 113. Jednym z nich był Andrej Lyzlov; por. M. P. Lukičëv, E. V. Čistâkova, K biografii avtora "Skifskoj istorii» A. I. Lyzlova, w: Arheografičeskij ežegodnik za 1986 god, Moskva 1987 [М. П. Аукичёв, Е. В. Чистякова, К биографии автора «Скифской истории» А. И. Аьъзова, w: Археографический ежегодник за 1986 год, Москва 1987], s. 289-297, tu: s. 296; również E. V. Čistâkova, Biofragiâ A. I. Lyzlova, w: A. I. Lyzlov, Skifskaâ istoriâ, Moskva 1990 [Е. В. Чистякова, Биография А. И. Аьъзлова, w: А. И. Аызлов, Скифскал история, Москва 1990, s. 355-359, tu: s. 358. Drugiego, Puskina, można być może identyfikować z okolniczym carskim Ivanem F. Puškinem; por. M. T. Poe (with O. Kosheleva, R. Martin, B. Morozov), The Russian elite in the seventeenth century / Rossijskaâ êlita v 17-om veke [Российcкаs элита в 17-ом веке], vol. 1: The consular and ceremonial ranks of the Russian "sovereign's court" 1613-1713 / Dumnye i ceremonial'nye ciny gosиdareva dvora 1613-1713 gg. [Аумные и меремониальные чины государева двора 1613-1713 22.], Vammala 2004, s. 301. 
z informacjami pochodzącymi od dwóch dworzan carskich uczestniczących w kampanii. Musieli oni opuścić wojsko Golicyna niedługo po rozpoczęciu odwrotu spod Perekopu (31 (21) maja), w tekście nie ma bowiem mowy o dalszych wydarzeniach. Owo końcowe zdanie należy niewątpliwie do redakcji samego Reyera, ponieważ tej treści komentarz nie mógłby znaleźć się w relacji rosyjskiej wysyłanej z obozu. Dodatkowo za autorstwem brandenbursko-pruskiego dyplomaty może przemawiać rozległe skreślenie powstałe przy jego redagowaniu. W rezultacie należy przyjąć, że miejscownik ,anhero” oznacza Królewiec. W pozyskaniu wieści o przebiegu wyprawy mogli pośredniczyć dwaj sokolnicy carscy, Ignatij Emelânov i Iwan Stepanovič, którzy wraz z elektorskim poselstwem przybyli do Prus i pozostawali w tym kraju do końca sierpnia 1689 r. ${ }^{41} \mathrm{Ci}$ z kolei mogli otrzymać rosyjski tekst relacji przywieziony do Moskwy przez wspomnianych uprzednio stolników, a następnie wysłany do Prus z dworu moskiewskiego. Między początkiem czerwca a przełomem sierpnia i września było wystarczająco dużo czasu, by wiadomości z wojska Golicyna dotarły do Moskwy, a stamtąd jeden z odpisów relacji choćby trasą wiosennego powrotu poselstwa Reyera przez Twer, Nowogród Wielki, Psków, Rygę i Kłajpedę doszedł do Królewca ${ }^{42}$. Jest to chyba bardziej prawdopodobny wariant wydarzeń aniżeli przyjęcie, iż rosyjska relacja została przywieziona przez carskich dworian do Królewca bezpośrednio z naddnieprzańskich stepów.

Podstawą tekstu Johanna Reyera była zatem relacja rosyjska wysłana z wojska Golicyna przebywającego jeszcze w polu podczas trwającej kampanii. Trudno wątpić wobec tego, by nie miała ona charakteru narracji oficjalnej skierowanej na dwór carski, stawiającej działania wojska rosyjskiego i jego wodza naczelnego w korzystnym świetle. Jest to zresztą jaskrawo widoczne w krótkim, jednozdaniowym podsumowaniu efektów całego przedsięwzięcia. Dalsze badania źródłoznawcze oparte na dokładnym porównaniu treści rosyjskiego zrębu relacji Reyera z innymi przekazami

41 GStA PK, XX. HA, EM 131a, Nr. 171, 173; por. S. Hartmann, op. cit., s. 186.

42 W 1668 r. po otwarciu trasy pocztowej między Moskwą a Rygą posłańcy drogę przez Nowogród Wielki i Psków pokonywali w ciągu 9-11 dni; por. R. Wittram, op. cit., s. 74-75. Możliwe było także wykorzystanie trasy pocztowej z Moskwy do Hamburga via Wilno-Królewiec, na której przewóz listów między skrajnymi punktami trwał wówczas trzy tygodnie; por. ibidem, s. 75. 
proweniencji rosyjskiej oraz staranna kwerenda archiwalna być może pozwolą w przyszłości zidentyfikować rosyjskojęzyczny przekaz będący podstawą tekstu brandenbursko-pruskiego posła. W tym miejscu można jedynie zauważyć, że przeprowadzona na potrzeby tych rozważań kwerenda niemieckojęzycznych druków ulotnych z okresu 1689-1700 przyniosła rezultaty negatywne.

Cała partia początkowa niemieckiej relacji, w której jest mowa o okolicznościach podjęcia wyprawy i o składzie wojska rosyjskiego ${ }^{43}$, pochodzi prawdopodobnie z rosyjskiego tekstu, który jednak wykazuje cechy nie tyle relacji zredagowanej dla dworu carskiego, o której była mowa wyżej, ile przekazu informacyjno-propagandowego przeznaczonego dla dworów zagranicznych. Wskazywałby na to sam tytuł relacji, a to z uwagi na jednoznaczną stylizację retoryczną, w której wyraźne pozostaje perswazyjne nastawienie do odbiorcy (relacja jest nazwana "prawdziwą" (wahrhafftige) i „dokładną” (außführliche), tj. niczego niepomijającą ani niezakrywająca). Biorąc pod uwagę wcześniejsze spostrzeżenia o wysłaniu rosyjskiej relacji z obozu wojskowego Golicyna jeszcze w trakcie kampanii, trzeba stwierdzić, że tego rodzaju informacyjno-propagandowe pismo musiałoby być odpowiednio przeredagowaną w Prikazie Poselskim (Посольский Приказ) wersją tejże relacji ${ }^{44}$. Być może przyszłe badania i kwerendy archiwalne zaowocują jej odnalezieniem.

Mając najprawdopodobniej do dyspozycji oficjalną rosyjską relację z kampanii 1689 r., Reyer nie dokonał bynajmniej prostego tłumaczenia

43 Obejmuje ona dwa pierwsze długie zdania; por. niżej: Aneks źródtowy, s. 109-110.

44 Por. m.in. oficjalną relację z kampanii krymskiej 1687 r. rozsyłaną do dworów zagranicznych przez Prikaz Poselski: A. P. Bogdanov, "Istinnoe i vernoe skazanie» o I Krymskom pohode $1687 \mathrm{~g}$. - pamâtnik publicistiki Posol'skogo prikaza, w: Problemy izučeniâ narrativnyh istočnikov po istorii russkogo Srednevekovâ. Sbornik statej, Moskva 1982 [А. П. БогАанов, «Истинное и верное сказание» о I Крымском походе 1687 г. - памлтник публицистики Посольского приказа, w: Проблемы изучения нарративных источников по истории русского Средневековья. Сборник статей, Москва 1982], s. 57-84, tu: s. 63-69: Istinnoe i vernoe skazanie o byvšem pohode velikih gosudarej ih carskogo veličestva vojsk na krymskih tatar nynešnâgo 1687-go goda [Истинное и верное сказание о бывшем походе великих государей их ијарского величества войск на крымских татар ньцешняго 1687-го года]. Za wskazanie tego materiału źródłowego dziękuję Koledze dr. Siergiejowi Polechowowi. 
tekstu rosyjskiego na język niemiecki, ale raczej sparafrazował podstawę narracyjną, do jakiej miał dostęp w Królewcu. Mogą o tym świadczyć choćby zamiana rosyjskich wiorst na mile przy podawaniu odległości geograficznych ${ }^{45}$ oraz określanie wojska carskiego mianem „armii moskiewskiej” (armée von Moschkowitischen) ${ }^{46}$. Z drugiej strony pozostawił on przyimki dzierżawcze wskazujące na identyfikację autora podstawy narracyjnej ze stroną rosyjską, jak również rachubę czasu według kalendarza juliańskiego.

Jak przedstawia się treść interesującej nas tu niemieckojęzycznej relacji? Tytuł sugeruje, iż koncentruje się ona na bitewnym starciu wojsk carskich z ordami chana krymskiego, które zostało zlokalizowane pod Perekopem i czasowo usytuowane w ciągu trzech dni: 15, 16 i 17 maja 1689 r. (według rachuby juliańskiej). Nie odpowiada to rzeczywistości, narracja dotyczy bowiem większości czasu przebiegu ponad czteromiesięcznej wyprawy, a nie tylko owych trzech dni. Relacja nie wspomina o poprzednim pochodzie przeciwko chanowi z 1687 r., jednak stawia opisywane działania w kontekście wojny koalicji złożonej z cesarza rzymskiego, Korony Polskiej i Republiki Weneckiej, wskazując, iż było to powtórne przedsięwzięcie sił rosyjskich. Na wyprawę zostały wedle tej narracji „z największym wysiłkiem” (mit großten depencer) zgromadzone na Ukrainie wojska rosyjskie i kozackie - nazywane odpowiednio „moskiewskim” i „czerkaskim”. Relacja wymienia głównych dowódców oraz strukturę polową wojska. Wspomina zatem wodza naczelnego, tj. generalissimusa kniazia-wojewodę Vasilija Vasileviča Golicyna, następnie dowódcę postępujących na prawym skrzydle sił nowogrodzkich (opisywanych jako Nowogrodische armée) wojewodę Alekseja Semionoviča Szeina ${ }^{47}$, dowódcę sił lewej flanki wojewodę Borysa Petroviča Šeremeta (Šeremeteva) ${ }^{48}$, dowódcę straży przedniej (z francuska zwanej „awangardą”) Iwana Stepanoviča Mazepę ${ }^{49}$ oraz do-

45 Por. niżej przyp. 53.

46 Por. niżej: Aneks źródtowy, s. 109.

47 O jego dworskiej i wojskowej aktywności por. M. T. Poe (with O. Kosheleva, R. Martin, B. Morozov), op. cit., s. 464.

48 Ibidem, s. 465.

49 Odnośnie do udziału hetmana w wyprawie krymskiej por. V. M. Zaruba [B. M. 3apyбa], op. cit., s. 70-74. O samym hetmanie por. m.in. V. V. Stanìslavs'kij, Mazepa Ivan Stepanovič, hasło w: Enciklopediâ istorï Ukrä̈ni, t. 6, red. V. A. Smolìj ì ïn, Kï̈v 2009 
wódców dwóch grup straży tylnej ('ariergardowych', również określanych jako 'arméen’) wojewodów Vlodimira Dimitrieviča kniazia Dolhorukiego (Dolgorukova) ${ }^{50}$ oraz Leontija Romanoviča Neplûeva ${ }^{51}$. Lokalizacja usytuowania wszystkich wymienionych sześciu zgrupowań w obrębie całego wojska jest podana w relacji wyprzedzająco, zanim jeszcze następuje w niej krótka wzmianka o skoncentrowaniu (rendewus) tych sił w Samarze, skąd wyruszyły one w stepy. Nieścisłe jest również włączenie w skład sił rosyjskich wojska kozackiego, które dołączyło do oddziałów Golicyna dopiero pod ową twierdzą. W relacji wyraźnie podkreślone zostały trudy marszu oddziałów rosyjskich pod Samarę, co miało odbyć się przy olbrzymim wysiłku (nach außgestandenen unsäglichen fatigen) przy niesprzyjających zimowych i wczesnowiosennych warunkach pogodowych i złym stanie szlaków drogowych. Odległość, jaką pokonały wówczas siły carskie, została oceniona na 250 mil $^{52}$. Wojsko carskie zebrane pod Samarą musiało w świetle omawia-

[B. В. Станіславський, Мазепа Іван Степанович, hasło w: Eнииклопедія історї̈ України, т. 6, ред. В. А. Смолій і їн, Київ 2009], s. 421-425; Т. G. Tajrova-Âkovleva, Ivan Mazepa i Rossijskaâ imperiâ: istoria "predatel'stva», Moskva 2011 [Т. Г. Таирова-Яковлева, Иван Мазепа и Российская империя: история «предательства», Москва 2011]; Th. Mackiw, Ivan Mazepa, Hetman der Ukraine und Reichsfürst des Heiligen Römischen Reiches, 1639-1709. Eine historische Skizze, „Jahrbuch der Ukrainekunde” 1983, Bd. 20, s. 127-151 (w tych pracach dalsza rozległa literatura).

50 Por. M. T. Poe (with O. Kosheleva, R. Martin, B. Morozov), op. cit., s. 403.

51 Ibidem, s. 428.

52 Jeżeli założyć, że Reyer stosował rachubę mili dolnoniemieckiej (7420 m), wówczas odległość ta wynosiłaby ca $1855 \mathrm{~km}$, w przypadku posługiwania się jednostką mili (staro)pruskiej $(7785 \mathrm{~m}$ ) byłoby to już ca $1950 \mathrm{~km}$. W każdym razie dane te mogły odnosić się jedynie do oddziałów w pułku nowogrodzkim. A. V. Lavrent'ev [A. В. Ааврентьев], op. cit., s. 143, podaje odległość z Moskwy do Achtyrki wynoszącą 723 wiorsty (ca $771 \mathrm{~km}$ ). Jako że z danych diariusza kampanii wynika odległość 108 wiorst (ca 115) dzieląca Achtyrkę od Samary (por. A. V. Lavrent'ev, op. cit., Priloženie [A. В. Ааврентьев, op. cit., Приложение], s. 147), oznacza to, że z Moskwy do Samary wojsko Golicyna pokonało ca 835 wiorst (ca 890,5 km). Pewne wątpliwości co do miary odległości stosowanej przez brandenbursko-pruskiego dyplomatę wzbudza porównanie danych z relacji wskazujących na 12-milową odległość, w jakiej znalazły się wojska Golicyna od Perekopu po wykonaniu marszu etapowego 25 (15) maja, której odpowiada wyliczona na podstawie informacji z diariusza kampanii odległość 25 wiorst $(26,67 \mathrm{~km})$. Jeżeli przyjąć, że rosyjska podstawa tekstu Reyera zawierała taką samą informację o odległości między siłami Golicyna a Perekopem 25 (15) maja, wówczas oznaczałoby to, że mila w relacji posła księcia-elektora miała 
nej narracji wypocząć przed wyruszeniem w stepy. Wymarsz spod twierdzy odbył się 3 maja (23 kwietnia). Wojsko rosyjsko-kozackie szło wedle analizowanego przekazu przez pustkowia, cierpiąc braki w żywności i furażu, jak również doświadczając braków w wodzie pitnej. Ten ostatni fakt relacja łączy z rzekomym zatruciem wody w niewielkich rzekach spływających do Dniepru. Z tych powodów miało umrzeć wielu ludzi. Wraz z nadejściem pełnej wiosny także upały i kurz miały powodować wielkie niedogodności w marszu. Nad rzeczką Kairką (Каирка) doszło wedle relacji do pierwszych potyczek (scharmizeln) z przeciwnikiem. W dniu 25 (15) maja, a więc po ponad trzech tygodniach drogi, wojsko zbliżyło się na ok. $12 \mathrm{mil}^{53}$ od Perekopu. Tu miało nastąpić pierwsze duże starcie z siłami tatarskimi, dowodzonymi przez samego chana. Relacja nie podaje jego imienia, wskazując tylko, że towarzyszyli mu dwaj najważniejsi murzowie w państwie, tj. nureddin i kałga sułtan ${ }^{54}$, wojsko składało się zaś z ord krymskiej, nogajskiej oraz białogrodzkiej (akermańskiej), którym towarzyszyły oddziały posiłkowe, mianowicie wiele tysięcy Gruzinów, Czerkiesów i Kałmuków. Łącznie wielkość sił chańskich została określona na 200000 ludzi. W dość retorycznie ustylizowany sposób wskazane zostało, iż siły rosyjsko-kozackie zostały otoczone przez oddziały chańskie. Ich atak miał zostać odparty ogniem kartaczowym z dużych dział, który spowodował śmierć kilku tysięcy napastników. Wspomniano o nich pogardliwie, iż „musieli kąsać trawę”. W odparciu ataku miała uczestniczyć rosyjska kawaleria - w większości oddziały złożone z carskich dworian. Bitwa miała zakończyć się opuszczeniem pobojowiska przez siły chańskie. W ciągu następnych dwóch dni (tj. 26 i 27 (16 i 17) maja) przeciwnicy wedle narracji ponownie dokonywali ataków na wojsko rosyjsko-kozackie, starając się uniemożliwić mu dotarcie do bezimiennej rzeczki, przy której chciano zaopatrzyć się w słod-

ca 2,22 km. Zastosowanie tego z kolei przelicznika do poprzedniej wzmianki o 250 milach dałoby odległość ca $555,5 \mathrm{~km}$, a zatem niespójną względem powyżej przywołanych wyliczeń A. V. Lavrent'eva. Jedynie na marginesie można tu zauważyć, że francuska relacja F. de la Neville'a zawiera informacje o odległościach przeliczone na francuskie mile (lieues); por. Relation campagne..., s. 95-96 (= De la Nevill' [Ае ма Невимль], ор. cit., s. 84-85).

53 Por. przyp. 52.

54 W 1689 r. nureddinem był Zamet (Azamat) Girej, zaś kałgą sułtanem Dewlet Girej; por. L. Podhorodecki, Chanat Krymski..., s. 227-228. 
ką wodę $e^{55}$. Batalia, do której tu doszło, miała podobny przebieg do starcia sprzed dwóch dni, strona tatarska miała zaś w niej stracić jeszcze więcej żołnierzy niż poprzednio, w tym wielu murzów, a wśród rannych miał się znaleźć sam nureddin, tj. książę-następca tronu. Podkreślono w relacji bogate łupy zwycięzców w postaci chorągwi, buńczuków, koni i wielbłądów. W rezultacie chan miał zostać zmuszony do odwrotu i schronienia się za umocnieniami Perekopu. W trakcie tego odwrotu wojsko chańskie wedle narracji niszczyło i wycinało za sobą trawę i zboża, zasypywało studnie i rujnowało budynki, aby utrudnić zaopatrzenie sił Golicyna. Relacja wspomina również o wysłaniu przez naczelnego wodza jeszcze przed bitwą w stepie znacznego oddziału piechoty pod dowództwem różnych, niewymienionych z imienia, generałów, który przeprawiony na statkach zaatakował Krym od strony morza, zaskakując mieszkańców i zdobywając liczne łupy. Natomiast wojsko zmierzające w kierunku Perekopu zastało na przesmyku potężne umocnienia złożone $\mathrm{z}$ podwójnego wału i głębokich fos ${ }^{56}$. Umocnienia miały być obsadzone licznymi ciężkimi działami oraz janczarami ${ }^{57}$. W tym miejscu relacja wskazuje, że można było z pewnością podjąć atak na umocnienia, ale $\mathrm{z}$ uwagi na braki w żywności i furażu byłyby to działania prowadzące do „zrujnowania” wojska. Stąd ograniczono się do podsunięcia artylerii pod miasto-twierdzę Perekop i zbombardowania jej, w rezultacie czego miała ona zostać zniszczona. Następnie zarządzono odwrót. Miano spodziewać się pościgu ze strony wojska chańskiego, ten jednak nie nastąpił. Chan wysłał natomiast jednego ze swoich murzów z propozycjami pokojowymi, które jednak kniaź Golicyn odrzucił. Relacja wskazuje, iż ukontentowano

55 Chodzi tu o Kolončak (ob. Kalančak/Каманчак); por. N. G. Ustrâlov, op. cit., Priloženie nr 11 [Н. Г. Устрямов, ор. cit., Приможение № 11], s. 370-371.

56 Odnośnie do umocnień perekopskich por. Księga podróży Ewliji Czelebiego (wybór), tłum. Z. Abramowicz, A. Dubinski, S. Płaskowicka-Rymkiewicz, red. Z. Abramowicz, Warszawa 1969, s. 225-231, 430-431 (przyp. 136-137).

57 Chodzi tu najpewniej o tzw. segbanów (z turecka nazywanych także sejmenami (seğmen)), tj. oddział przyboczny chana stanowiący stałą jednostkę i zorganizowany w 1532 r. na wzór osmańskich janczarów przez Sahib Gireja, dowodzony zazwyczaj przez Turków i otrzymujący żołd z Wysokiej Porty, nierzadko wykonujący zadania o charakterze policyjno-porządkowym; por. L. Podhorodecki, Chanat Krymski..., s. 101-102. 
się tym, że przeciwnik został kilkakrotnie pokonany w polu, stracił wielu ludzi, wojska carskie okazały się zaś zwycięskie.

Bliższa analiza zaprezentowanego przekazu przeprowadzona z punktu widzenia budowy narracji i struktury zawartych w niej treści pozwala na wyciągnięcie pewnych wniosków odnośnie do form postrzegania i pojmowania działań wojennych zarówno przez twórcę/-ów pierwotnej relacji wysłanej z rosyjskiego obozu wojskowego jeszcze w trakcie wyprawy krymskiej, a następnie najprawdopodobniej przeredagowanej w Prikazie Poselskim, jak i przez samego Johanna Reyera redagującego wersję niemieckojęzyczną dla księcia-elektora. Mamy tu mianowicie do czynienia z przekazem, który w swojej pierwotnej redakcji zawierał 'narrację wodzowsko-dworską'. Prowadzona jest ona wedle porządku chronologicznego. Charakterystycznym jej elementem jest ujęcie wydarzeń w kontekście działań wodza wojska. Jego osoba jest ukazana w sytuacjach, które nie zawsze mają związek ze sprawami kierownictwa militarnego, ale każdorazowo pozwalają ukazać osobiste zalety wodza. Taką funkcję spełnia wzmianka o wodzu naczelnym cierpiącym wraz z pozostałymi dowódcami niedogodności pochodu, na które wystawione jest jego wojsko, a tym niedogodnościom poddawany jest on niemniej aniżeli zwykli żołnierze. Mamy tu do czynienia z jednym z najczęściej stosowanych toposów narracji o wydarzeniach militarnych wodza bliskiego swoim wojownikom/żołnierzom. Jest on tym bardziej nieprzystający do XVII-wiecznej rzeczywistości, iż nie uwzględnia funkcjonowania ukształtowanej już wówczas kadry oficerskiej i podoficerskiej, której pozycja w wojsku rosyjskim, w tym także warunki bytowe, wyraźnie odróżniała się od gemeinów ${ }^{58}$. Wzmianka o wojewodzie nieprzyjmującym propozycji pokojowych chana krymskiego, który jest ukazany jako pokonany, bez wątpienia jest formą budowy obrazu zwycięskiego wodza dyktującego pokonanemu warunki dalszego działania. Jej propagandowa funkcja nie ulega wątpliwości w świetle znanych przekazów źródłowych mówiących o prowadzonych przez obie strony rokowaniach, w których Golicyn

58 W tej kwestii por. C. B. Stevens, Rosyjskie wojny 1460-1730. Narodziny mocarstwa [oryg.: Russia's wars of emergence, 1460-1730, Harlow a.o. 2007], tłum. K. Jackiewicz, Warszawa 2010, s. 232-237. 
nie był bynajmniej stroną występującą z pozycji przewagi ${ }^{59}$. Jednocześnie przyczyny, dla jakich oferta pokojowa chana została odrzucona, nie zostały przedstawione. Perspektywa dworska analizowanej narracji uwidacznia się we fragmencie dotyczącym carskich kawalerzystów kontratakujących siły chańskie pierwszego dnia bitwy, wśród których wspomniani są jedynie szlachetni dworianie, podczas gdy w realiach ówczesnej organizacji wojska rosyjskiego większość pułków kawalerii była sformowana wedle wzorów tzw. nowej organizacji, a więc składała się bynajmniej nie z członków dworu moskiewskiego i ludzi mieszkających przy innych pomniejszych rezydencjach carskich ${ }^{60}$.

Drugim aspektem dostrzegalnym w relacji jest topiczność innych jeszcze wątków. Odnosi się to przede wszystkim do typowych wyznaczników narracyjnych sukcesu wojennego. Tak więc pojawia się w tekście wzmianka o zabitych przeciwnikach w pierwszej bitwie z 25 (15) maja oraz w trzecim starciu z 27 (17) maja, jak również w trakcie potyczki nad rzeczką Kairką oraz w podsumowaniu efektów całego przedsięwzięcia. Topiczność tych fragmentów narracji stanie się jeszcze wyraźniejsza, jeśli uwzględni się brak jakichkolwiek informacji o stratach własnych w każdym z owych czterech miejsc narracyjnych. Innym elementem topicznym jest wspominanie o łupach wojennych, które zdobywa zwycięskie wojsko rosyjskie. W przypadku informacji o działaniach wojska wysłanego statkami na Krym ${ }^{61}$ jest to nawet jeden z dwóch wątków (obok splądrowania obszaru przeciwnika), za pomocą których autor pierwotnej rosyjskiej narracji chciał wyrazić skalę sukcesu tego przedsięwzięcia. Podobny charakter ma wzmianka o zniszczeniu miasta-twierdzy Perekop za pomocą bombardowania artyleryjskiego. Wpisuje się ona w schemat narracyjny, wedle którego pokonanemu przeciwnikowi niszczone są miejsca jego egzystencji.

59 Por. Relation campagne..., s. 103-107 (= De la Nevill' [Ае ма Невимль], ор. cit., s. 86-87); Irži David [Иржи АавиА], op. cit., s. 127; oraz literaturę przywołaną w przyp. 28.

60 Por. odnośnie do tego zagadnienia niedawne studium P. Krokosza, Rosyjskie sity zbrojne za panowania Piotra I, Kraków 2010, s. 96-101 (tu dalsza, szeroka literatura); także C. B. Stevens, op. cit., s. 232-233.

61 Chodzi tu najpewniej o działania Kozaków dońskich, którzy z Czerkaska podjęli akcję w rejonie Keczu (tatar. Keriç). 
Topika narracyjna pojawia się nie tylko jako zabieg stylistyczny umożliwiający udowodnienie i przekonującą reprezentację własnego zwycięstwa. Podobny charakter ma wspomnienie zatrucia wody w rzekach uchodzących do Dniepru, co przekazane w odpowiedniej formie retorycznej urasta do rangi głównej przyczyny problemów aprowizacyjnych wojska i strat przez nie ponoszonych. Za topos należy także uznać wyolbrzymienie liczebności przeciwnika. Również przywołanie okrzyków tatarskich rozlegających się ze wszystkich kierunków służy za narracyjną ozdobę przekazu i niewiele może mieć wspólnego z percypowaną przez zbrojnych carskich rzeczywistością rozległego na całe kilometry pola bitwy 25 (15) maja.

Trzecim aspektem analizowanej relacji jest niski poziom spójności implikatywnej narracji i warunkowana przezeń duża ogólnikowość opisu. Mianowicie w żadnym miejscu przekazu poszczególne okoliczności i wydarzenia rozgrywające się w wojsku rosyjskim nie zostały przedstawione w na tyle szczegółowy sposób, by narracja mogła zyskać większy potencjał wyjaśniający opisywane wypadki. Zależności między poszczególnymi zjawiskami i wypadkami są sprowadzone do najprostszych relacji chronologicznego sąsiedztwa i nie ma w nich wspomnianej implikatywności. I tak przekaz podkreśla, że wojsko rosyjskie idące przez stepy cierpiało na braki zaopatrzeniowe $z$ uwagi na przemierzany teren i panująca pogodę, przy czym dodatkową wyszczególnioną przyczyną jest podkreślane już zatrucie rzek przez przeciwnika. W jaki sposób siły chańskie były w stanie na kilku różnych trasach pochodu poszczególnych zgrupowań połączonych wojsk rosyjskiego i kozackiego dokonać tak rozległych zniszczeń oraz owych zatruć, tego relacja jednak nie wyjaśnia. Nie wyjaśnia też ani słowem, co się stało z materiałami aprowizacyjnymi zabranymi przez wojsko rosyjskie, które miały wystarczyć na dwa miesiące, tj. mniej więcej do końca czerwca. Czy do czasu dramatycznych dla żołnierzy Golicyna wydarzeń w naddnieprzańskich stepach zostały one zupełnie wyczerpane, czy właśnie zaczęły się kończyć? Nie sposób też uznać za wyjaśniającą narracji o podjęciu decyzji o odstąpieniu od szturmu umocnień perekopskich przez siły carskie, skoro wedle relacji wojska znajdowały się w dobrym stanie, a przede wszystkim podchodziły pod Perekop jako zwycięzcy. Bitwy z 25 (15) i 27 (17) maja zostały opisane ogólnikowo wedle identycznego schematu narracyjnego (odparcie ataku sił chańskich ogniem kartaczowym dział i kontratak 
kawalerii). Nie da się uzyskać z przekazu wyjaśnienia, w jaki sposób rosyjska kawaleria zmuszała w tych starciach do odwrotu atakujących rzekomo ze wszystkich stron Tatarów i ich sprzymierzeńców. Bitwa z 26 (16) maja w ogóle nie została zaprezentowana. Odległość 250 mil pokonanych przez oddziały rosyjskie pozostaje całkowicie zawieszona w próżni narracyjnej. Nie wiadomo, kto i skąd przemierzył taki dystans. Wszystkie te przykłady pokazują jednocześnie, iż wysokiemu poziomowi ogólnikowości opisu i niskiej spójności implikatywnej narracji towarzyszy również niezwykle niski stopień autorefleksyjnego krytycyzmu. Wszystkie te spostrzeżenia niejako pośrednio wskazują na informacyjno-propagandowy charakter relacji rosyjskiej w postaci przeredagowanej w Prikazie Poselskim. Trzeba na koniec jeszcze raz podkreślić, że poziom owej informatywności nie jest zbyt wysoki.

Jeśli wziąć pod uwagę ukazane wyżej prawdopodobne okoliczności powstania niemieckiego tekstu relacji, to okaże się, iż wprawdzie wszystkie powyższe spostrzeżenia dotyczące struktury treści i budowy narracji należy odnosić do przekazu rosyjskiego, jednak pozostają one wiążące przynajmniej w części również dla redakcji Johanna Reyera. Przejął on bowiem zasadniczy zrąb informacyjno-propagandowej narracji rosyjskiej, w zasadzie nie ingerując w jego treść, a tym bardziej nie opatrując go żadnymi krytycznymi komentarzami. Obserwacje te wskazują na to, że Johann Reyer funkcjonował w podobnych strukturach mentalnych pojmowania i analizy zdarzeń wojennych, jak członkowie ówczesnej rosyjskiej elity dworskiej i wojskowej ${ }^{62}$. W końcowej partii przekazu znajduje się wspominany już, dodany przez Reyera passus zawierający wyjaśnienie okoliczności, w jakich relacja z wyprawy dotarła na dwór moskiewski i do niego. Poprzedza go zdanie mające charakter komentujący, które również wyszło spod ręki brandenbursko-pruskiego dyplomaty. Jest to jedyny komentarz będący zarazem wynikiem pewnej, nieskomplikowanej autorefleksji, jaką Reyer musiał podjąć, aby dojść do przedstawionego wniosku. Wskazuje on mianowicie, iż opisane w relacji działania militarne były przedsięwzięciem bezprecedensowym i nie sposób w związku z tym stwierdzić, czy inne europejskie

62 W kwestii charakterystyki społecznej elity dworskiej, aczkolwiek bez uwzględnienia uwarunkowań kulturowych, por. M. T. Poe (with O. Kosheleva, R. Martin, B. Morozov), op. cit., s. 9-24, 47-63. 
nacje byłyby w stanie podobną wyprawę wojenną przeprowadzićc ${ }^{63}$. Można przypuszczać, że w pierwszym rzędzie Reyer mógł odnosić to do pozostałych członków Ligi Świętej. Zawarta jest w tej opinii ogólna ocena wyprawy krymskiej jako wielkiej i skomplikowanej kampanii. Mogła ona zostać sformułowana jedynie po myślowym zestawieniu i dokonanej na jego podstawie analizie porównawczej innych znanych Reyerowi z przebiegu działań wojennych, a przy tym musiała być efektem indukcyjnie wyprowadzonych uogólnień. Ten jeden przejaw krytycznego racjonalizmu Reyera w żadnym razie nie oznacza, iż był on w stanie dokonywać szerszych i bardziej złożonych procesów analitycznych w odniesieniu do zagadnień militarnych. Już choćby nieporadność językowa dyplomaty widoczna w używaniu - zgodnym z resztą z powszechną ówczesną praktyką - francuskiego terminu armee do opisu dwóch różnych poziomów organizacji wojska carskiego sama w sobie musiała być jednym z czynników utrudniających mu pogłębioną, tj. zróżnicowaną, autorefleksję nad sprawami militarnymi, opartą na krytycznym podejściu, ścisłej terminologii i wariantowych rozumowaniach.

Co pokazuje casus Johanna Reyera? Czy mówi cokolwiek o funkcjonowaniu struktur militarnych zachodnioeuropejskiego kręgu kulturowego w końcu XVII w.? Był on przecież urzędnikiem nadwornym i dyplomatą z wykształceniem prawniczym, ale nie wojskowym. Zarazem jednak prezentował dość wysoki poziom intelektualny, w tym zdolności językowe, nie mówiąc o umiejętnościach epistemologicznych i społecznych w zakresie obserwacji, komunikacji i dyskursu ${ }^{64}$. Należy zdać sobie sprawę z tego, że

63 Por. niżej: Aneks źródtowy, s. 113.

64 O rozległości horyzontów myślowych Johanna Reyera może świadczyć jego korespondencja z Gottfriedem Wilhelmem Leibnizem; por. K. Forstreuter, Reyher, Johann..., s. 552; idem, Preußen und Rußland..., s. 175; ponadto L. Richter, Leibnitz und sein Rußlandbild, Berlin 1946. Nieprzeciętne umiejętności dyplomatyczne pruskiego posła i tajnego radcy ukazuje fakt, iż w końcu 1689 r. udało mu się całkowicie zneutralizować starania chińskiego posła, a zarazem jezuity, genueńczyka Claudio Filippo Grimaldiego, starającego się o uzyskanie carskiego zezwolenia na wolny przejazd dla jezuitów z Europy do Chin przez obszary Rosji; por. R. Widmeier, Leibnitz'verborgene Botschaft in den Novissima Sinica, w: Das Neueste über China. G. W. Leibnizens Novissima Sinica von 1697, Hrsg. W. Li, H. Poser, „Studia Leibnitiana: Supplementa”, vol. 33, Stuttgart 2000, s. 29-56, tu: s. 42, przyp. 62 na s. 42-43; M. C. Carhart, Leibnitz discovers Asia. Social networking in the republic of letters, Baltimore 2019, s. 1-2. 
mamy do czynienia z postacią nieprzeciętną, o kontakt z którą w krótkim czasie po analizowanych tu zdarzeniach zabiegał nie kto inny jak Gottfried Wilhelm Leibniz ${ }^{65}$. Chociaż Reyer nie prowadził ani nie przygotowywał żadnego przedsięwzięcia militarnego, to jako poseł elektorski był w końcu XVII w. dla kręgów kierowniczych monarchii Hohenzollernów dostarczycielem wiadomości o krajach, ludziach, wydarzeniach i zjawiskach, z którymi się spotykał i które do niego docierały. Dane militarne również należały do tego zbioru informacji. Na podstawie tekstów przesyłanych przez Reyera książę-elektor i grono głównych dowódców sił zbrojnych państwa Hohenzollernów pozyskiwali tego rodzaju dane o sprawach militarnych innych krajów. Jak zostało pokazane, dane te miały zaledwie pewien potencjał informacyjny, ale były pozbawione jakiegokolwiek właściwie potencjału analitycznego. Zatem nawet jeśli w kręgu wojskowych pozostających na służbie Hohenzollernów w końcu XVII w. znaleźliby się ludzie zdolni do racjonalnej oraz systematycznej analizy, krytycznej refleksji w kwestiach militarnych, opartej na złożonych rozumowaniach indukcyjnych, to informatorzy pokroju Reyera nie byliby w stanie dostarczyć im do tego odpowiedniej jakości danych. Niniejszy przyczynek pokazuje, iż w długim procesie racjonalizacji spraw militarnych, który był istotnym elementem szerszego fenomenu ważnych przemian zachodzących w wojskowości zachodnioeuropejskiej, począwszy od drugiej połowy XVII w., konkretną rolę odgrywały nie tylko czynniki militarne, społeczne i państwowe - intensywnie analizowane w literaturze przedmiotu - ale także różnorodne czynniki kulturowe. W końcu bowiem Reyer do służby dyplomatycznej nie został wykształcony i przygotowany w jakimś państwowym bądź nawet dworskim instytucie edukacyjnym, lecz zarówno jego pewne umiejętności i predyspozycje, jak też brak innych były efektem socjalizacji nabytej w ówczesnym społeczeństwie i kulturze Brandenburgii-Prus doby drugiej połowy XVII w. Reyer był więc „dzieckiem społeczeństwa” i „dzieckiem kultury” w ich całościowych ówczesnych przejawach, niezdolnym do systematycznej racjonalnej analizy opartej na rozumowaniu indukcyjnym. W kulturze tej, kulturze kręgu zachodniego, właśnie w pokoleniu Reyera dopiero co zarysowywały się początki przełomu racjonalistycznego, stojącego u podstaw krytycznego,

65 Por. R. Widmeier, op. cit., s. 38, 42-43. 
systematycznego i dążącego zarazem do koherentności oglądu świata. Było to przecież pokolenie wspomnianego wyżej Gottfrieda Wilhelma Leibniza $(* 1646, \uparrow 1716)$ oraz Isaaca Newtona $(* 1742, \uparrow 1727)$, który w roku pierwszej wyprawy krymskiej (1687) publikował swoje przełomowe Philosophiae naturalis principia mathematica stojące w centrum tzw. nowożytnej rewolucji naukowej ${ }^{66}$. Zmieniająca się wojskowość zachodnioeuropejska miała w ów racjonalistyczny przełom wejść z mniej więcej jedno- bądź nawet dwupokoleniowym opóźnieniem, wraz z osobami m.in. Maurycego Saskiego (Maurice de Saxe, $\left.{ }^{*} 1696, \uparrow 1750\right)^{67}$, Fryderyka II Wielkiego $\left({ }^{*} 1712\right.$, $\dagger 1786)^{68}$ oraz Henry’ego Humphreya Evansa Lloyda (* ca 1718/1720, $\dagger 1783)^{69}$.

66 Por. m.in. J. Black, The power of knowledge..., s. 110, $112 \mathrm{i}$ w szerszej perspektywie s. 104-116 (tu dalsza literatura zagadnienia).

67 Francuski marszałek był autorem Les reveries ou memoires sur l'art de la guerre wydanych pośmiertnie w 1756 r.; w kwestii jego teoretycznych refleksji nad rzemiosłem wojennym por. A. Gat, A history of military thought from the Enlightenment to the Cold War, Oxford 2001, s. 32-35 oraz C. Telp, The evolution of operational art, 1740-1813. From Frederick the Great to Napoleon, „Military History and Policy”, vol. 20, London-New York 2005, s. 5-6; M. Vego, op. cit., s. 95-96.

68 Por. jego Les principes generaux de la guerre / Die General-Principia vom Kriege z lat 1746-1748/1752-1753; odnośnie do teoretycznej myśli wojskowej Fryderyka II Wielkiego por. A. Gat, A history of military thought..., s. 58-60 oraz C. Telp, op. cit., s. 6-8, 22-23 (w obu pracach dalsza literatura przedmiotu); w polskim piśmiennictwie historycznowojskowym sumarycznie L. Wyszczelski, Historia myśli wojskowej, Warszawa 2000, s. 119-120.

69 Pierwsze dzieło Lloyda The history of the late war in Germany between the king of Prussia and the empress of Germany and her allies wydrukowano w 1766 r. (pierwsze anonimowe niemieckie tłumaczenie ukazało się w 1777 r., niebawem zaś wyszło tłumaczenie Georga Friedricha von Tempelhoffa: Geschichte des Siebenjährigen Krieges in Deutschland zwischen dem Könige von Preußen und der Kaiserin Königin mit ihren Alliierten wydane między 1783 a 1794 r.), drugie Reflections on the principles of the art of war w $1781 \mathrm{r}$. Odnośnie do teoretycznej myśli Lloyda obok przytoczonego wyżej tomu zbiorowego por. m.in. podstawowe studium P. J. Speelmana, Henry Lloyd and the military Enlightenment of eighteenth-century Europe, „Contributions in Military Studies”, no. 221, Westport-London 2002 oraz A. Gat, A history of military thought..., s. 69-78; C. Telp, op. cit., s. 23-24; R. Vierhaus, op. cit., s. 190-193; M. Vego, op. cit., s. 96-97; w polskim piśmiennictwie L. Wyszczelski, op. cit., s. 121-122. 
Aneks źródłowy

Relacja niemieckojezyczna o przebiegu wyprawy krymskiej $1689 r{ }^{*}$

Oryginat: nieznany

Brudnopis: Geheimes Staatsarchiv Preußischer Kulturbesitz, XX. Hauptabteilung (Historisches Staatsarchiv Königsberg), Etats-Ministerium, Abt. 131a, Nr. $126, k .1 r-2 v$

Uwagi: Ztożony arkusz papieru w formacie folio, wymiary $33 \times 21,5 \mathrm{~cm}$, 2 karty; brak znaku wodnego; brak podpisu

[k. $1 r]$

Wahrhafftige und außfürhrliche Relation von dem dreÿtägigen Tref$\mathrm{fen}^{\mathrm{a}}$, auch ${ }^{\mathrm{b}}$ verschiedenen rencontren, so zwischen Ihr. Ihr. Her. Czar. M. Mäy[esteten] undt denn Tartarischen Han mit ${ }^{c}$ seinen Horden unter Perekop geschehen den 15, 16, 17 Maÿ 1689.

Nach dem die Großen Herren Ihre Ihre Her. ${ }^{d}$ Czar. M[äyesteten] krafft der mit Ihren Käÿserl[ichen] Mäÿ[este]t, dann mit Ihren Königl[ichen] Māȳ[este]t undt der Crohn Pohlen, wie auch mit der Resp. Venedig geschloßenen alliance abermahl eine große armée von Moschkowitischen

* Edycja źródłowa została przygotowana wedle wytycznych opracowanych przez J. Schultzego, Richtlinien für die äußere Textgestaltung bei der Herausgabe von Quellen zur neueren deutschen Geschichte, „Blätter für deutsche Landesgeschichte” 1962, Jg. 98, s. 1-11 (= „Blätter für deutsche Landesgeschichte” 1966, Jg. 102, s. 1-10 = w: Richtlinien für die Edition Landesgeschichtlicher Quellen, Hrsg. W. Heinemeyer, Marburg-Köln 1978, s. 25-36). Zachowane zostały jedynie rozróżnienia wszelkich stosowanych przez autora znaków diakrytycznych (np. ä, ā, ÿ, ȳ). Oddano także wiernie pisownię wielkich i małych liter.

a Stowo nadpisane nad skreślonym wyrazem Bataille.

b Stowo nadpisane nad skreślonym wyrazem undt.

c Stowo nadpisane nad skreślonym wyrazem undt.

d Stowo poprawione z Czar. 
undt Czerkastischen nation mit ${ }^{\mathrm{e}}$ großten depencer formieren laßen, derselben sich in der Ukrain wieder den Tartarischen Han zu gebrauchen, wurdt selbige folgender gestalt befunden. Das Corpo führte Seine fürstl[iche] Gnade Kniaz Wasili Wasilewicz Goliczyn ${ }^{\mathrm{f}}$ als Generalissimus, die Nowogrodische armée war im rechten fliegel unterm Bojar undt Woywode Alexy Semenowicz Schein. Den lincken fliegelg commandirte der Bojar undt Woÿwod Borys Petrowicz Szeremet ${ }^{\mathrm{h}}$ die $^{\mathrm{i}}$ avangarde bestunde in der Czerkaßischen armée unterm feldtherren Iwan Szczepanowicz Mazepa, undt die arrieregarde von Rezanischen undt Siewischen arméen unterm commando des beeden Bojaren undt Woÿwoden fürst Wlodimir Dimitrowicz Dolhoruki undt Leontey Romanowicz Nepluzet. Das rendewus selbigen armée geschehe beÿ der neu angelegte festung Samara allwo mann nach außgestandenen unsäglichen fatigen in einem marsch von 250 Meÿlen $^{\mathrm{k}}$ passirung beÿ beschwehelichen winthers undt vorjahres wetter so wider bösen wege, gewäßerns und morräste in etwas außgeruhet. Den 23. April ist Sie von dar auffgebrochen, undt durch große wüste felder beÿ mangel [k. 1v] der lebens-mittel und fourage den marsch weiter fortgestezet. An wasers hat mann auch grosten Mangel gehabt, masten dann in den kleinen flüßen, so in den Dniepr fallen, es sehr ungesund waßer giebt, weil es mit allerhand angezieffer angefüllet ist. Daran viel Menschen ${ }^{1}$ gestorben, die hitze und der staub hat auch große incommeditel veruhrsachet. Gleichwoll hat der her Generalissimus mit beÿhabenden Bojaren und Woÿwoden dieses große Ungemach ${ }^{\mathrm{m}}$ überstanden. Als mann sich dem Strümchen Kairka nähern wollen, sind verscheidenene scharmizels mit dem feinde vorgangen.

e Stowo nadpisane nad kolejnym wyrazem großten. Wcześniej pięć stów skreślonych.

f Stowo naniesione na lewym marginesie.

g Skreślone litery Kom.

h Skreślone stowo In.

Stowo poprawione $z$ der.

' Nieczytelne skreślenie: [rende....].

k Nieczytelne skreślenie czterech liter.

1 Stowo napisane nad następnym wyrazem gestorben.

m Przedrostek Un nadpisany nad reszta wyrazu. 
Davon ${ }^{\mathrm{n}}$ etliche hunderts ${ }^{\mathrm{n}}{ }^{\mathrm{o}}$ getödtet, auch etliche gefangen worden ${ }^{\mathrm{p}}$ Den 15. Maÿ frühe ${ }^{q}$ hatte mann $^{-q}$ auff 12 . Meÿlen ${ }^{r}$ dem Perekop ${ }^{s}$ sich genähert da kahm der Tartarische Han mit seinen beÿden Prinzen Nuradyn und Galga und mit ihnen der gantze schwarm der Krymischen Nagaischen undt Belogradischen Horden ${ }^{\mathrm{t}}$ nebenst ${ }^{\mathrm{u}}$ viel 1000 Gorges[chen], Czerkaßischen, Kalmukischen undt andern auxiliar Völcken, ${ }^{\mathrm{v}-s o}$ wie 200000 Mann starck waren ${ }^{-v}$, die machten an allen orthen ein großes geschreÿ mit ihren gewöhnlichen Halla! Halla! ${ }^{\text {w-Sie }}$ fuechten ${ }^{-\mathrm{w}}$ die unsrigen an, wurden aber auß dem groben geschütz mit ketten-kugeln dergestalt bewillkemmet, daß etliche 1000 darüber ins graß beißen müsten. Auch wurden Sie von unserer Cavallerie, so meistens aus Czarichen Hoffedelleüthen bestanden tapffer angegrieffen, daß Sie ${ }^{\mathrm{x}}$ selbigen tages nach großem Verlußt in confusion das feldt haben räümen müßen. Den 16. undt 17. giengen Sie etliche mahl auff die unsrige loß, und wolten Ihren den anmarsch gegen einem kleinen flüßchen, darinn süßes, waßer wary ${ }^{y}$, verschneiden, wurden aber ${ }^{z}$-in beÿden tagen nach vielstundigen scherffen gefecht ${ }^{-z}$ durch kartatschen und durch ${ }^{\text {aa }}$ die cavallerie zur retierden gezwungen mit großtenn verlußt der Ihrigen und $\mathrm{t}^{\mathrm{ab}}$ darunter $[k .2 r]$ vieler vornehmen Mursen ${ }^{\mathrm{ac}}$. Unter den blessirts ist der Sultan Nuradyn. Auch sindt ${ }^{\text {ad }}$ viele gefangen. Mann hat

n Stowa naniesione na marginesie, wprowadzone do wiersza za pomoca znaku pisarskiego.

- Skreślone stowo eins.

p Skreślone stowa: Als mann.

q Stowa nadpisane nad wyrazem auff.

r Nieczytelne skreślenie wyrazu.

s Skreślone stowa: kommen, nahrte.

t Skreślone stowa: unndt mit.

u Stowo naniesione na lewym marginesie.

- Fraza zapisana na marginesie, wprowadzona do wiersza za pomoca znaku pisarskiego po skreślonym zapisie: in 200000 mann starck.

w Wyrazy nadpisane nad skreślonym stowem Fechten.

x Wyraz poprawiony z die.

y Stowo nadpisane nad wierszem.

z Fraza zapisana na marginesie, wprowadzona do wiersza za pomoca znaku pisarskiego.

aa Stowo nadpisane nad następnym wyrazem die.

ab Stowo nadpisane nad następym wyrazem darunter.

ac Dwa stowa skreślone, nieczytelne.

ad Stowo nadpisane nad następnym wyrazem viele 
ee-eine große Menge-ae Fähnlein, Bunczuken pferde undt Kamehl erobert. Der Tartarische Sultan ist gezwungen worden sich hinter dem Perekop in großer confusion zu reteriren. Allwo er auff viel Maÿlen das graß und Gethreüde abhauen, zernichten, gebäude ruiniren, die $^{\text {af }}$ brunnen mit steinen verwerffen laßen, umb dergestalt unserr armée alle subsistentz-mittel zu benehmen. Etliche tage vor dem großen bataillen ließag der herr Generalissimus eine guthe anzahl infanterie unter commando unterschiedlichen Generalspersohnen zu waßer nach Krym übersezen. Sie haben des Einwohner in der $^{\text {ah }}$ größesten sicherheit gefunden, viel davon niedergemachet, dörffer in brandt gestecket, undt sind mit guthe beüthe zurückkommen. Als nun die gantze armée weiter bis an die Mauern vor Perekop gerucket, fandt mann von einem ende des Schwartzen Meeres ${ }^{\text {ai }}$ biß ans andere einen hohen doppelten wall mit tieffen graben, die völle waren mit vielen groben geschütz und mit janitzscharen besezet. Mann hatte zwar den orth ${ }^{j j}$ woll angegreiffen $^{\text {-aj }}$ können, aber weil keine lebens mittel vor menschen noch futter vors viehe vorhanden ${ }^{\text {ak }}$ war $^{\text {al }}$, were es unserer armeé ruin ${ }^{\text {am }}$ gewesen. Deswegen man sich nur an die Stadt Perekop gemachet, und als selbige mit Bomben ruiniret worden, ${ }^{\text {nn-hat }}$ mann $^{\text {-an }}$ mit der ganzen armée sich zurückgezogen. Mann meÿnte der feindt würde dadurch veranlaßet werden unß in den rücken zu gehen, so aber nicht geschehen. Vielmehr hat der Han mit gewißen friedens Puncten einen Mursen an den Generalissmen gesand, die aber auß wichtigen ursachen nicht angenommen worden. Deßmahl hat mann sich damit contentiert, daß der feindt etlich mahl auß dem

ae Fraza zapisana na marginesie, wprowadzona do wiersza za pomoca znaku pisarskiego $w$ miejsce skreślonego wyrazu viel.

af Stowo nadpisane nad skreślonym wyrazem undt.

ag Stowo nadpisane nad skréslonym wyrazem schickte.

ah Stowo nadpisane nad wierszem.

ai Stowo nadpisane nad skreślonym wyrazem Wasers.

aj Stowa nadpisane nad skreślonym, nieczytelnym wyrazem [f.....].

ak Stowo nadpisane nad skreślonym wyrazem gewesen.

al Stowo nadpisane po nadpisanym skréllonym, nieczytelnym wyrazie naniesionym nad nastęnym stowem were.

am Stowo nadpisane nad skré́lonym, nieczytelnym wyrazem.

an Stowa naniesione na lewym marginesie. 
felde geschlagen worden ${ }^{\text {ao }}$, der Seinigen viel verlohren, ${ }^{\text {pp-und }} \mathrm{da} ß$ also-ap $^{-a}$ durch Gottes Seegen ${ }^{\text {aq }}$ Ihr Ihr. Her. Czar. M[aÿesteten] ${ }^{\text {ar }}$ waffen ${ }^{\text {ss- }}$ siegreich gemachet worden. ${ }^{-a s}$ Mann [k. 2v] hat kein Exempel, daß einige Europeische nationen "t-in $\mathrm{Krym}^{\text {at }}$ dergleich was ${ }^{\text {au }}$ außgerichtet. Dieße zeithungen sindt auß dem lagerav durch die Czarische Stolniken Puskin undt Lislaf und durch $^{\text {aw }}$ ander, welche beÿ allen der aberzehlten Actionen mitzugegen ${ }^{\text {ax }}$ gewesen, anhero gebracht worden.

ao Stowo nadpisane nad skreślonym wyrazem unndt, po którym następuja trzy skreślone, nieczytelne wyrazy, w tym dwa nadpisane nad wierszem.

ap --pp Stowa nadpisana nad sześcioma skreślonymi wyrazami: durch die [...?] Seinig unndt das.

aq Nieczytelne skreślenie wyrazu.

ar Skreślone stowo siegreich.

as Fraza nadpisana nad następnym wyrazem Mann.

at --tt Wyrazy naniesione na marginesie obok skreślonego zapisu in Kry.

au Stowo nadpisane nad skreślonym, nieczytelnym wyrazem.

av Skreślone, nieczytelne stowo [angele.....].

aw Stowo nadpisane nad następnym wyrazem ander.

ax -zugegen nadpisane nad nastepnym wyrazem gewesen. 
